\title{
The lower Aptian ammonites of the Les Ferres Aptian Basin (Lower Cretaceous, Southeast of France)
}

\section{Part I: Introduction and biostratigraphy}

\begin{abstract}
Stéphane BERSAC ${ }^{1,2}$
Didier BERT ${ }^{1,3}$

Abstract: On the southern margin of the Vocontian Basin (SE France), for taphonomic reasons (fragmentation, reworking, pyritization), lower Aptian (Lower Cretaceous) deposits of the interval between the Deshayesites deshayesi and Dufrenoyia furcata zones are usually not suitable for studying the late ontogenetic developments of ammonites (fossil cephalopods). In the vicinity of the village of Les Ferres (Department of the Alpes-Maritimes, SE France), a relatively thick sedimentary succession with wellpreserved ammonites, representative of the zones mentioned above, is found in a small basin called the "Les Ferres Aptian Basin" (LFAB). The 1262 ammonites collected or studied in situ are dated from the Deshayesites forbesi Zone through the top of the Dufrenoyia furcata Zone. This study presents the lithostratigraphy, biostratigraphy derived from these ammonites, and the respective range of these taxa. This is an introductory contribution to any future palaeontological study of the lower Aptian ammonites in the Les Ferres area. The lithologic unit overlying the Hauterivian-Aptian limestones is introduced herein as the Les Graous Formation. It is subdivided in three members, from bottom to top: 1 ) the Combe de Joinet Member, 2) the Pont de la Cerise Member, and 3) the Les Graous Member. In addition, two remarkable levels are identified: the Ammonitoceras level (outstandingly abundant) and the Toxoceratoides bed.
\end{abstract}

\section{Key-words:}

- Southeast of France;

- lower Aptian;

- biostratigraphy;

- ammonites

Citation: BersaC S. \& BERT D. (2019).- The lower Aptian ammonites of the Les Ferres Aptian Basin (Lower Cretaceous, Southeast of France). Part I: Introduction and biostratigraphy.- Carnets Geol., Madrid, vol. 19, no. 9, p. 149-183.

Résumé : Les ammonites de l'Aptien inférieur du bassin aptien de Les Ferres (Crétacé inférieur, SE de la France). $I^{\text {ère }}$ partie : Introduction et biostratigraphie.- Sur la marge méridionale du Bassin Vocontien (SE de la France), les dépôts d'âge aptien inférieur (Crétacé inférieur) de l'intervalle situé entre les zones à Deshayesites deshayesi et Dufrenoyia furcata ne sont habituellement pas favorables à l'étude des développements ontogénétiques tardifs des ammonites (céphalopodes fossiles) pour des raisons taphonomiques (fragmentation, remaniement, pyritisation). Dans les environs du village de Les Ferres (département des Alpes-Maritimes, SE de la France), des sédiments aptiens relativement épais et riches en ammonites bien conservées relevant de l'intervalle stra-tigraphique précité se sont déposés dans un petit bassin structural dénommé ici bassin aptien de Les Ferres (LFAB). Les 1262 ammonites collectées ou étudiées in situ sont datées de la Zone à Deshayesites forbesi jusqu'au sommet de la Zone à Dufrenoyia furcata. La lithostratigraphie, la biostratigraphie fondée sur les ammonites et la distribution de leurs taxons respectifs sont décrits dans ce travail qui constitue une introduction litho- et biostratigraphique à de futurs travaux paléontologiques sur les ammonites de l'Aptien inférieur du secteur des Ferres. Au-dessus des calcaires hauteriviens à aptiens, une nouvelle formation lithologique est décrite, la Formation de Les Graous. Elle est divisée en trois membres, de bas en haut : 1) Membre de la Combe de Joinet, 2) Membre du Pont de la Cerise et 3) Membre de Les Graous. Deux niveaux remarquables y sont identifiés : le niveau à Ammonitoceras (exceptionnellement abondants) et le banc à Toxoceratoides.

\footnotetext{
${ }^{1}$ Laboratoire du Groupe de recherche en paléobiologie et biostratigraphie des Ammonites, Bois-Mésanges, quartier Saint-Joseph, 04170 La Mure-Argens (France)

${ }^{2}$ geosteber@yahoo.fr

${ }^{3}$ Réserve naturelle nationale géologique de Haute-Provence, service Environnement, Conseil départemental des Alpes de Haute-Provence, 13, rue du Docteur-Romieu, CS 70216, 04995 Digne-Les-Bains cedex 9 (France) Laboratoire Géosciences, UMR-CNRS 6118, université de Rennes-1, campus Beaulieu, bâtiment 15, 35042 Rennes cedex (France) didier.paleo@gmail.com
}

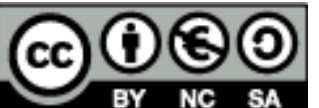

Published online in final form (pdf) on August 8, 2019

[Editor: Michel MOULLADE; language editor: Simon MITCHELL; technical editor: Bruno GRANIER] 


\section{Mots-clefs :}

- sud-est de la France ;

- Aptien inférieur ;

- biostratigraphie ;

- ammonites

\section{Introduction}

In the Vocontian Basin (Southeast of France), upper lower Aptian ammonite faunas (middle Deshayesites deshayesi to Dufrenoyia furcata zones sensu BERSAC et al., 2012; see Fig. 1) have been repeatedly described and figured (SAYN, 1920; THOMEL, 1963, 1964, 1968; DAUPHIN, 2002; Dutour, 2005; Joly \& DelametTe, 2008). Nevertheless, their study is limited by several factors:

- they are generally preserved as small pyrite nuclei, which makes the study of their ontogeny difficult;

- heteromorph ammonites are generally underrepresented in the Vocontian Basin for taphonomical reasons (DAUPHIN, 2002; DUTOUR, 2005) and because they were not adapted to a pelagic environment (WESTERMANN, 1996; LUKENEDER, 2015);

- the conditions are usually unfavorable for preservation of large heteromorph ammonites in the neritic margins of the Vocontian Basin, with the upper lower Aptian either being absent or represented by reworked deposits yielding only fragmented ammonites (BERSAC et al., 2010; PICTET et al., 2015).

Most of the large lower Aptian heteromorph ammonites in the Vocontian Basin that have been figured in the literature are older than the middle D. deshayesi Zone (sensu BERSAC et al., 2012; see Fig. 1 and ROCH, 1927; DeLANOY, 1998; DeLANoY et al., 2008; PICTET et al., 2009, 2015). A few of the more recent species that have been reported include Ammonitoceras ucetiae DuMAS, 1876 (DumAs, 1876) and Toxoceratoides? sp. inc. "Gigantomorph" godeti THIEULOY, 1990 [THIEULOY, 1990 = Lithancylus godeti (THIEULOY, 1990), see CONTE, 1999 and MiKHAILOVA \& BARABOSHKIN, 2001] from the Serviers-et-Labaume and Montaren-etSaint-Médiers area (Gard department, southeastern France; DUMAS, 1876). These ammonites come from the Deshayesites multicostatus Subzone ( $D$. deshayesi Zone sensu BERSAC et al., 2012) based on the evolutionary characters of the associated Douvilleiceratinae PARONA \& BONARELLI, 1897 (see BERSAC \& BERT, 2018).

The Les Ferres area is located in the lower Esteron Valley (Alpes-Maritimes Department, SE France), in the southern part of the Vocontian Basin. It was situated at the boundary between the neritic and hemipelatic domains during the early Aptian (Figs. 2 - 3). The Aptian series were deposited in a small E-W structural basin, within a series of tilted blocks. This palaeostructure, which is named herein the Les Ferres Aptian Basin (LFAB), was the site for the deposition of a relatively thick sedimentary sequence with numerous large ammonites. The interval from the

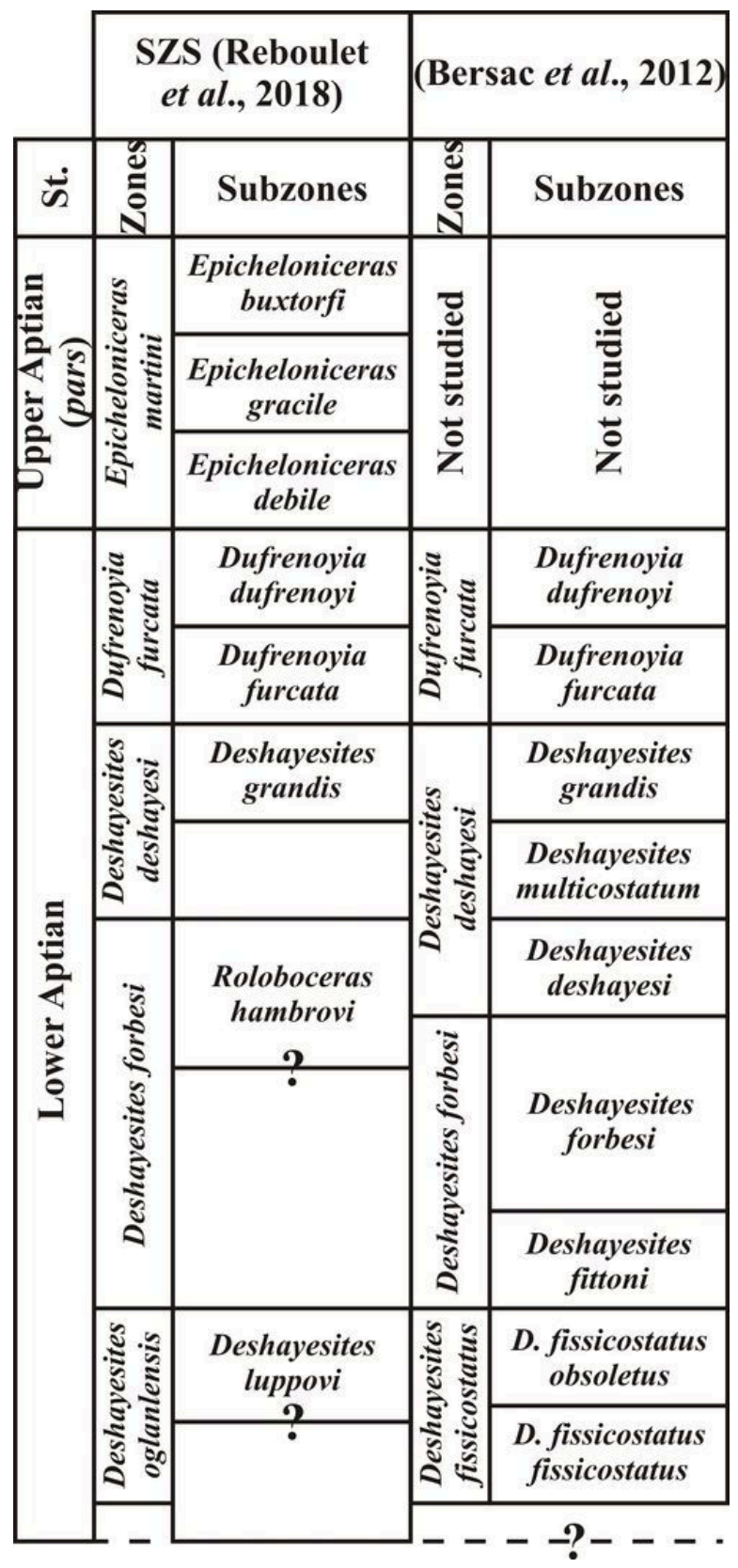

Figure 1: Biostratigraphic charts used in the present work. SZS: Standard Mediterranean Zonal Scheme. St.: stages. 


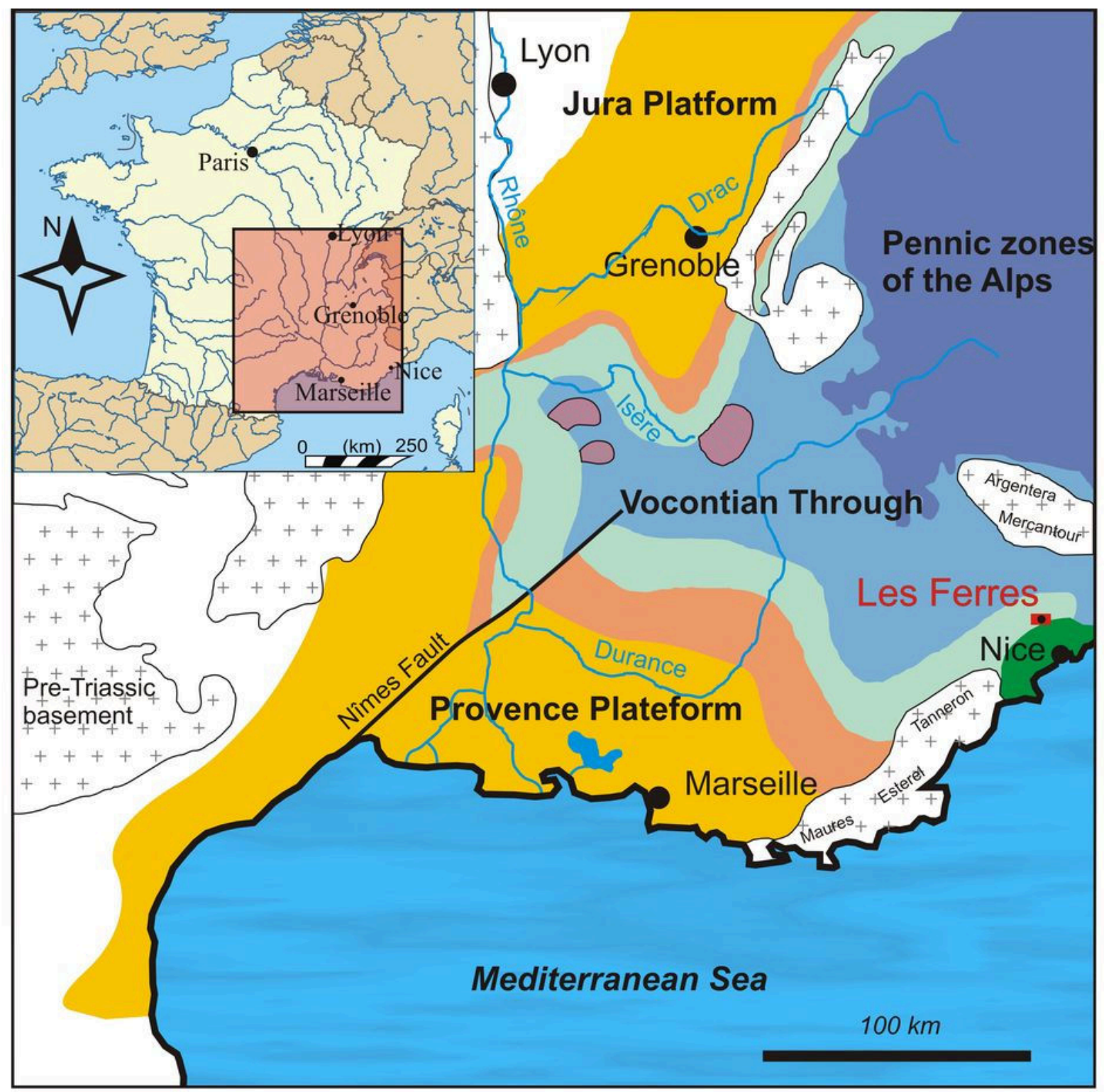

Deep open marine environment (pelagic)

\section{Shallow open marine environment (hemipelagic)}

\section{External platform}

Drowned platform (glauconitic condensed series)

\section{Inner platform}

\section{Gravity reworked deposits}

Figure 2: Location of the Les Ferres area in the Vocontian Basin (figure after BERSAC et al., 2010, amended).

Deshayesites forbesi to the Dufrenoyia furcata zones does not include any polyzonal or condensed intervals. The ammonite fauna is represented by the "classical" taxa described and figured in the pelagic domain (Dufrenoyia KILIAN \& ReBoul, 1915, Cheloniceras HyATT, 1903, Pseudohaploceras HYATT, 1900, Toxoceratoides SPATH, 1924 and Colombiceras SPATH, 1923, etc., see for example DuTOuR, 2005) associated with numerous heteromorph ammo- nites that belong mainly to the genera Ammonitoceras DumAs, 1876, Lithancylus CASEY, 1960, and Tropaeum J. de C. SOWERBY, 1837, which were previously poorly known in SE France. This material is sufficiently abundant and stratigraphically constrained to allow the study of evolutionary trends and intraspecific variability. In a nutshell, the LFAB is a unique locality to study ammonites of this time interval. 

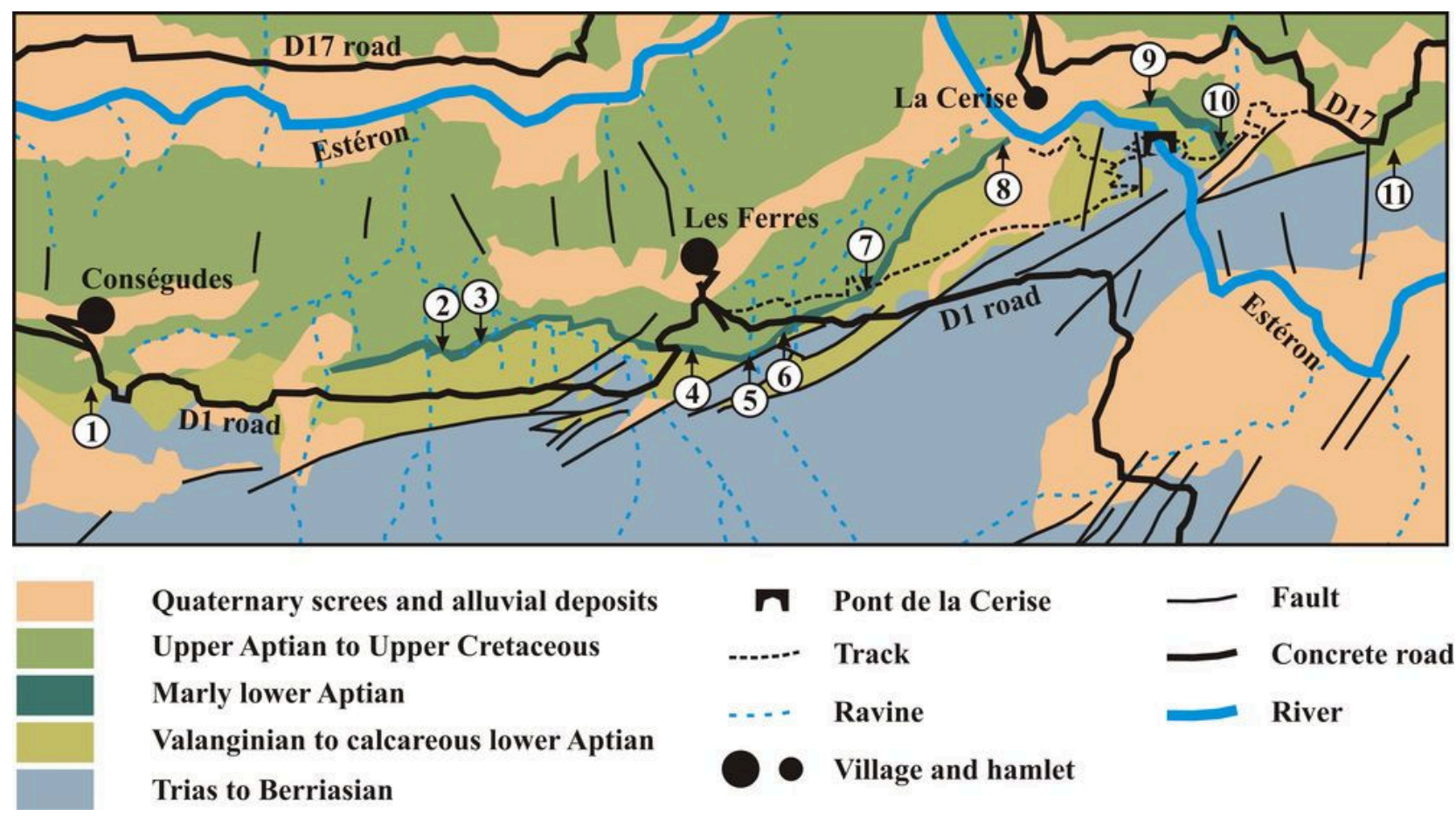

Quaternary screes and alluvial deposits

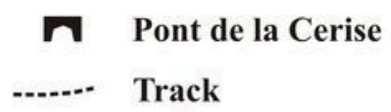

Upper Aptian to Upper Cretaceous

Marly lower Aptian

Valanginian to calcareous lower Aptian

Trias to Berriasian

\section{... Ravine}

Village and hamlet

Figure 3: Map of the Les Ferres area with location of the studied or mentioned sections. 1: Conségudes section; 2: Les Graous 2 section (GRS 2); 3: Les Graous 1 section (GRS 1); 4: unnamed section of the La Vallière locality studied by RAGAZZI (1982, p. 73), then BRÉHERET (1997, p. 267, Figs. 114-115); 5: La Vallière section (VAL); 6: La Graou section (GRO); 7: Combe de Joinet section (CHP); 8: Pont de la Cerise section (CLE); 9: Combe de Marin section (CRS); 10: Pont Païré section (PPR); 11: Colle-Belle section.

The objective of the present work is to describe the lithostratigraphy and biostratigraphy of the lower Aptian of LFAB, with the aim of supporting our future palaeontological studies of ammonites from this area.

\section{Palaeogeographic, structural and stratigraphic framework}

The studied outcrops all are located on the northern flank of Cheiron Mountain, in the vicinity of the village of Les Ferres (Fig. 3).

The study area belongs to the southern subalpine Castellane Arc, at the southern margin of the Vocontian Basin. It is part of a tectonic structure on the southern boundary of the Esteron Syncline, at the junction between two tilted blocks. This tectonic structure is characterized by the presence of WNW-ESE oriented half-grabens. The (synsedimentary) tectonics were active from the Valanginian to the Albian, and are responsible for the rapid lateral change in thickness and the numerous gaps that characterize the Lower Cretaceous succession in this area (DARDEAU, 1987; DARDEAU \& GRACIANSKY, 1987). This tectonic structure has also resulted in the formation of a small EW-oriented basin, in which the lower Aptian sediments were deposited. The Lower Cretaceous strata were deposited in the outer neritic domain. Their facies are intermediary between those of the hemipelagic units located to the northeast and those of the condensed neritic series located to the southeast (Cotillon, 1971; Bersac et al., 2010; Fig. 2).

The Aptian of the LFAB is represented by two main lithological units: a calcareous unit overlain by a plurimetric marly unit (COTILLON, 1971, 2010; RAGAZZI, 1982; Fig. 4); the calcareous unit and the lower part of the marly unit are referred to the lower Aptian and the rest of the marly unit to the upper Aptian. These deposits form a transgressive sequence (COTILLON, 1971) related to the "middle Bedoulian drowning event" (BRÉHERET, 1997; COTILLON, 2010; MASSE \& FENERCI-MASSE, 2011, p. 671). The present work focuses on the marly lower Aptian of the LFAB. Newly identified lithostratigraphic units are formally described in Chapter 5.2.

\section{Historical account of the Aptian ammonite palaeontology in the Les Ferres area}

FAllot (1885, p. 128) was the first author to indicate the possible presence of Aptian strata in the vicinity of Les Ferres. Subsequently, GoGUEL (1944), Cotillon (1971), Ginsburg et al. (1980), RAGAZZI (1982), and BRÉHERET (1997) have documented the lithostratigraphy and ammonite biostratigraphy of this area (see detailed historical accounts in RAGAZZI, 1982, and BRÉHERET, 1997). COTILLON (1971, p. 146), for instance, was the first to mention the presence of the ammonite genus Dufrenoyia (and consequently the presence of the D. furcata Zone, see Fig. 1) in the LFAB. However, 
several occurrences of ammonite taxa reported in these contributions were not supported by any illustrations. Our own investigations in the area started in the early 2000 s and resulted in preliminary publications (BERT \& BERSAC, 2011; BERT, 2014) including illustrations of few specimens. More recently, DELANOY et al. (2018) revisited the site. They figured and described these faunas in detail. These latter authors, focused on large heteromorphic ammonites and described ten new taxa.

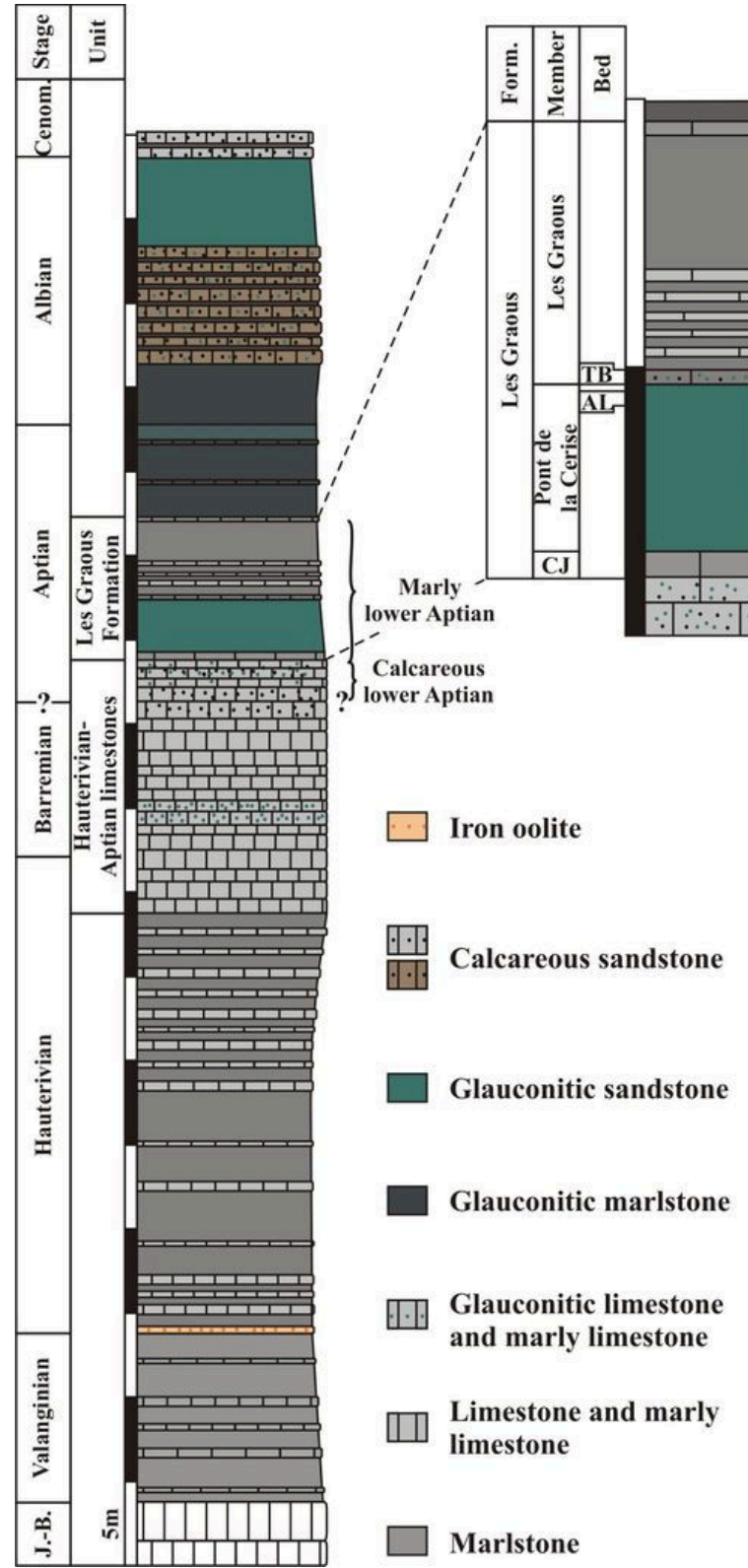

Figure 4: Synthetic log of the Lower Cretaceous of the Les Ferres area. J.-B.: Jurassic and Berriasian; Cenom.: Cenomanian; Form.: Formation; CJ: Combe de Joinet Member; AL: Ammonitoceras Level; TB: Toxoceratoides Bed.

\section{Methods}

\subsection{Lithostratigraphic units and sections}

To date, the lithostratigraphic units of the LFAB have not been formally described in the scientific literature. In the present work, we propose a formal lithostratigraphic scheme for the marly lower Aptian of the LFAB (Fig. 4 and see Chapter 5.2). The name of the recognized units is that of the outcrop where they are visible under the best conditions. Two remarkable levels are recognized and named according to the characteristics of their respective ammonite faunas.

\subsection{Biostratigraphic scheme}

The biostratigraphic scheme used in the present work is that previously proposed by BERSAC et al. (2012) for the lower Aptian, based on a review of the Deshayesitidae StoYanow, 1949 (Ammonoidea, BERSAC \& BERT, 2012, 2015; Fig. 1).

\subsection{Field sampling and material studied}

Our objective was to prospect all the Aptian outcrops of the LFAB. Nine sections were then identified and 8 of them were sampled (Fig. 3). Two other sections close to the study area were also studied: the Conségudes and the Colle-Belle sections. A total of 1,262 ammonites was bed-bybed sampled or studied in situ between 2000 and 2017. This material is deposited in the collections of the Laboratory of the Research Group for Paleobiology and Biostratigraphy of the Ammonites (G.P.A., France).

\subsection{Remarks about the material published by DELANOY et al. (2018)}

We were both present in the field when all the material published by DeLANOY et al. (2018) was extracted and we reviewed it once prepared. Therefore, we deemed it necessary to include it in our study. Our own field data differ somewhat from those of DELANOY et al. (2018), and we will explain these differences below where necessary. It should be noted that the designation of specimens published by DeLANOY et al. (2018) is complicated by the fact that several specimens may bear the same number, or that several numbers may be assigned to the same specimen. The problematic numbers are 28754, 28756, 28767, 28766, 28768, and 28769. Similarly, it should be noted that the holotype of Proaustraliceras bournaudi DELANOY et al. 2018, numbered AP-001 (DeLANOY et al., 2018, p. 47 and Fig. 7) does not belong to the BERSAC's collection contrary to the statement by these authors. 


\section{Results}

\subsection{Preliminary ammonite taxonomic CONSIDERATIONS}

In this chapter, we briefly discuss the taxonomic assignments used in our study for the sole purpose of providing support for the presentation of the lithostratigraphic and biostratigraphic results. In particular, according to our data, the new taxa introduced by DeLANoy et al. (2018) are all subjective synonyms of taxa already described. For this reason, these taxa are not quoted in the stratigraphic logs (Figs. 5, $7,9-10,12,14-15)$. We will expose our taxonomic positions in detail in future works.

5.1.1. The Deshayesitidae and Douvilleiceratidae PARONA \& BONARELLI, 1897

These two ammonite families provide lower Aptian zonal and subzonal index species for different palaeogeographic domains (CASEY et al., 1998; BARABOSHKIN \& MiKHAILOVA, 2002; REBOULET et al., 2018). The criteria for identifying Deshayesitidae used in this work are those proposed by BERSAC \& BERT $(2012,2015)$. They rely on the morphology of the ventral area and the suture lines. The taxa we identified in the LFAB are Deshayesites sp. (PI. 1, figs. 4-5), Deshayesites multicostatus SWINNERTON, 1935 (PI. 2, figs. 6-8, 13-15, 19), Deshayesites grandis SPATH, 1930 (PI. 3, figs. 9-12), Dufrenoyia furcata (J. de C. Sowerby, 1837) (PI. 5, figs. 59), and Dufrenoyia dufrenoyi (ORBIGNY, 1841) (PI. 5, figs. 30-32). The lower Aptian Douvilleiceratidae of the LFAB are only represented by Douvilleiceratinae. Their identification is based on the duration of their ontogenetic stages (see BERSAC \& BERT, 2018, and references therein). The identified taxa are Procheloniceras sp. (PI. 1, figs. 6-7), Cheloniceras sp. and Cheloniceras crassum SPATH, 1930 (PI. 2, figs. 16-17; PI. 3, figs. 5-6; Pl. 4, figs. 8-9).

\subsubsection{The Parahoplitidae Spath, 1922}

The collected material is assigned to the $D$. furcata Subzone (D. furcata Zone) (PI. 5, figs. 10-12). All intermediates can be observed from slender forms having a Colombiceras crassicostatum-type shape to robust forms with a Gargasiceras gargasensis-type shape. Consequently we consider Gargasiceras gargasensis (Orbigny, 1841) as a subjective synonym of Colombiceras crassicostatum (ORBIGNY, 1841), as already suggested by JACOB (1907), DUTOUR (2005) and BuLot (2010). Possible primitive representatives of Parahoplitidae occur in the Deshayesites grandis Subzone (D. deshayesi Zone) and are identified as ?Colombiceras sp.

\subsubsection{The Ancyloceratidae Mezk, 1876}

\subsubsection{Ammonitoceras}

The genus Ammonitoceras is represented by large ammonites with criocone, aspinoceratic or ancyloceratic coiling, characterized by the presence of a particular ontogenetic stage in the inner whorls: the Ammonitoceras stage. This stage is characterized by the presence of bituberculated main ribs bearing an umbilical tubercle and a lateral tubercle of larger size. In a future article, we will publish a detailed study of Ammonitoceras from the $D$. deshayesi and $D$. furcata zones of the LFAB. that:

Preliminary results from this study suggest

1. the genus Ammonitoceras shows significant intraspecific variability that mainly relates to the duration of the ontogenetic Ammonitoceras stage;

2. Ammonitoceras is probably sexually dimorphic, with large crioconic macroconchs (PI. 2, figs. 12 ; PI. 4, figs. 1-3) and microconchs with aspinoceratic or ancyloceratic coiling (PI. 2, figs. 3$5)$;

3. Ammonitoceras macroconchs of the $D$. furcata Zone (PI. 4, figs. 1-3) have on average an Ammonitoceras stage disappearing later during ontogeny and a narrower spiral hiatus than those of the D. multicostatus Subzone (PI. 2, figs. 1-2);

4. Ammonitoceras of the D. multicostatus Subzone can be assigned to the species Ammonitoceras ucetiae and those of the $D$. furcata Zone to Ammonitoceras lahuseni (SInzow, 1906);

5. we interpret Ammonitoceras dumasi DELANOY et al., 2018 as the macroconch of $A$. ucetiae and regard it as a subjective synonym of that species;

6. we interpret the following species and specimens as microconchs of $A$. ucetiae: Caseyites esteronensis DeLANOY et al., 2018, Caseyites vermeuleni DELANOY et al., 2018, Ammonitoceras madouxi Delanoy et al., 2018, Proaustraliceras bournaudi DelANoY et al., 2018, the specimen identified under ?Proaustraliceras sp. numbered 28766 or 28767 in DELANOY et al. (2018, p. 50-51, Fig. 9.A) and the specimen of Ammonitoceras aff. madouxi numbered 28764 in Delanoy et al. (2018, p. 71-72, Fig. 19);

7. according to our interpretation, $A$. leiferrasensis Delanoy et al., 2018, Caspianites ragazziae DELANOY et al., 2018, and the specimen figured under ?Caspianites sp. and numbered 28744 or 28754 in Delanoy et al., (2018, p. 83, Fig. 25.A-B and p. 84) are all macroconchs of $A$. lahuseni and thus subjective synonyms of that species;

8. in our view, Caseyites morenobedmari DeLANOY et al., 2018 is a microconch of $A$. lahuseni and consequently a subjective synonym of that species; and

9. Ammonitoceras specimens from the $D$. grandis Subzone are too incomplete to be identified at the specific rank. 


\subsubsection{Lithancylus}

Lithancylus of the D. multicostatus Subzone of the LFAB (PI. 2, figs. 11-12) appear to have significant intraspecific variability, which concerns both their ontogenetic sequence and adult size. In our opinion, these specimens belong to the species Lithancylus grandis (J. de C. SowER$\mathrm{BY}, 1828)$, and consequently we interpret $\mathrm{Li}$ thancylus bifurcatus DELANOY et al., 2018 as a subjective synonym of that species.

\subsubsection{The Helicancylidae HyATT, 1894}

On the basis of the diagnostic characteristics proposed by BULOT et al. (2017) and FRAU et al. (2017), we identified Toxoceratoides sp., Toxoceratoides aff. royerianus (ORBIGNY, 1842) (PI. 3, figs. 13-16) and Toxoceratoides rochi CASEY, 1961 (PI. 5, figs. 1-4).

\subsubsection{The Ptychoceratidae GILL, 1871}

The genus Ptychoceras ORBIGNy, 1842, is represented by rare specimens we identified as Ptychoceras emericianum ORBIGNY, 1842 (PI. 5, fig. 15) on the basis of the revision work of VERMEULEN et al. (2015).

\subsubsection{The Desmoceratidae ZitTeL, 1895}

We identified the Desmoceratidae of the LFAB on the basis of the diagnostic criteria proposed by DUTOUR (2005), in particular the aspect of the whorl section. In this respect, identification of the collected specimens at the specific rank was made difficult by the fact that they are almost always deformed and crushed. The taxa identified are: Pseudohaploceras sp. (PI. 1, fig. 8), Pseudohaploceras liptoviensis (ZeusChner, 1856) (PI. 2, figs. 9-10; PI. 4, figs. 6-7), Pseudosaynella sp., Aconeceras nisum (ORBIGNY, 1841) (PI. 5, figs. 13-14) and ?Aconeceras sp.

\subsubsection{The Lytoceratidae Neumayr, 1875}

Representatives of this family are rare in the LFAB and are attributed to Lytoceras sp. (PI. 4, figs. 10-11).

\subsubsection{The Macroscaphitidae HyATT, 1900}

Based on BuSNARDo's remarks (in GAUTHIER, 2006), we identified Macroscaphites aff. yvani (Puzos, 1832) and Macroscaphites striatisulcatus (OrbignY, 1841) (PI. 2, fig. 20; PI. 3, figs. 3-4; Pl. 5, fig. 16).

Following the works of WRIGHT et al. (1996), KLEIN et al. (2007) and VAŠíčEK et al. (2014), we consider Pseudocrioceratites EgOIAN, 1969, as a subjective synonym of Acantholytoceras SPATH, 1923. The Acantholytoceras we collected in the LFAB are too fragmented to be identified to specific level (PI. 4, figs. 4-5).

\subsubsection{The Phylloceratidae ZItTeL, 1884}

In the LFAB, this family is represented only by the subgenus Hypophylloceras SALFELD, 1924 (Phylloceras Suess, 1865). Joly \& Delamette (2008, Fig. 74) recognized 6 species of Phylloceras (Hypophylloceras) ranging through the $D$. deshayesi and D. furcata zones (sensu ReBoulet et al. 2018) in the Vocontian Basin. The diagnostic characters are subtle variations in ornamentation, section or morphology of the suture line. Our specimens are not sufficiently well preserved to be identified to the specific level (PI. 3, fig. 1; PI. 4, fig. 12).

\subsection{LITHOSTRATIGRAPHIC FRAMEWORK}

\subsubsection{Top of the Hauterivian-Aptian lime- stones (Fig. 4)}

In the neritic domain of the Castellane Arc, Hauterivian to lower Aptian deposits are represented by a pluridecametric succession of massive limestone beds. CotILLon (1971) divided it into a series of formations (formations 17 to 25, Cotillon, 1971, p. 34 and Fig. 12bis). In the LFAB, the HauterivianAptian limestones are represented by a plurimetric succession of massive decimetric limestone beds separated by centimetric marly intervals (Fig. 4) that have already been described in the literature under various names ("Calcaire blanc compacte" in FALLOT, 1885, p. 127, "Barrémo-Bédoulien" in RAGAZZI, 1982, p. 73).

The highest beds in the upper part of this lithological unit contain increasing amount of sandstone and glauconite (RAGAZZI, 1982), and corresponds to Cotillon's (1971) Formation 25, and these are assigned to the lower Aptian (pars, GinsBURG et al., 1980; RAGAZZI, 1982). The upper limit of the Hauterivian-Aptian limestones is represented by a firmground-type, with iron crust layers and extensive bioturbation by Rhizocorallium ZENKER, 1836 (Fig. 8.D). This discontinuity surface is correlated with the "early Aptian unconformity" (Cotillon, 2010, p. 4) that is related to the "middle Bedoulian drowning event" (MASSE \& FENERCI-MASSE, 2011, p. 671). It corresponds to a large-scale discontinuity surface formed during the flooding of the Provençal platform (BréHeret, 1997; Cotillon, 2010; MASSE \& FeNERCI-MASSE, 2011). This event is assigned to the upper D. forbesi Zone (PICTET et al., 2015; Fig. 1).

We only sampled the last Hauterivian-Aptian limestone bed: it is represented by a centimetric level of grey to yellowish sandstone relatively rich in internal moulds of ammonites, nautiloids and belemnites (Fig. 13.A). RAGAZZI (1982, p. 74-75) reported the following ammonite fauna: Ancyloceras audouli (ASTIER, 1851), Deshayesites latilobatus (Sinzow, 1910) [= 'D. latelobata (Sinzow)' in RAGAZZI, 1982, p. 75], Deshayesites sp., Cheloniceras 


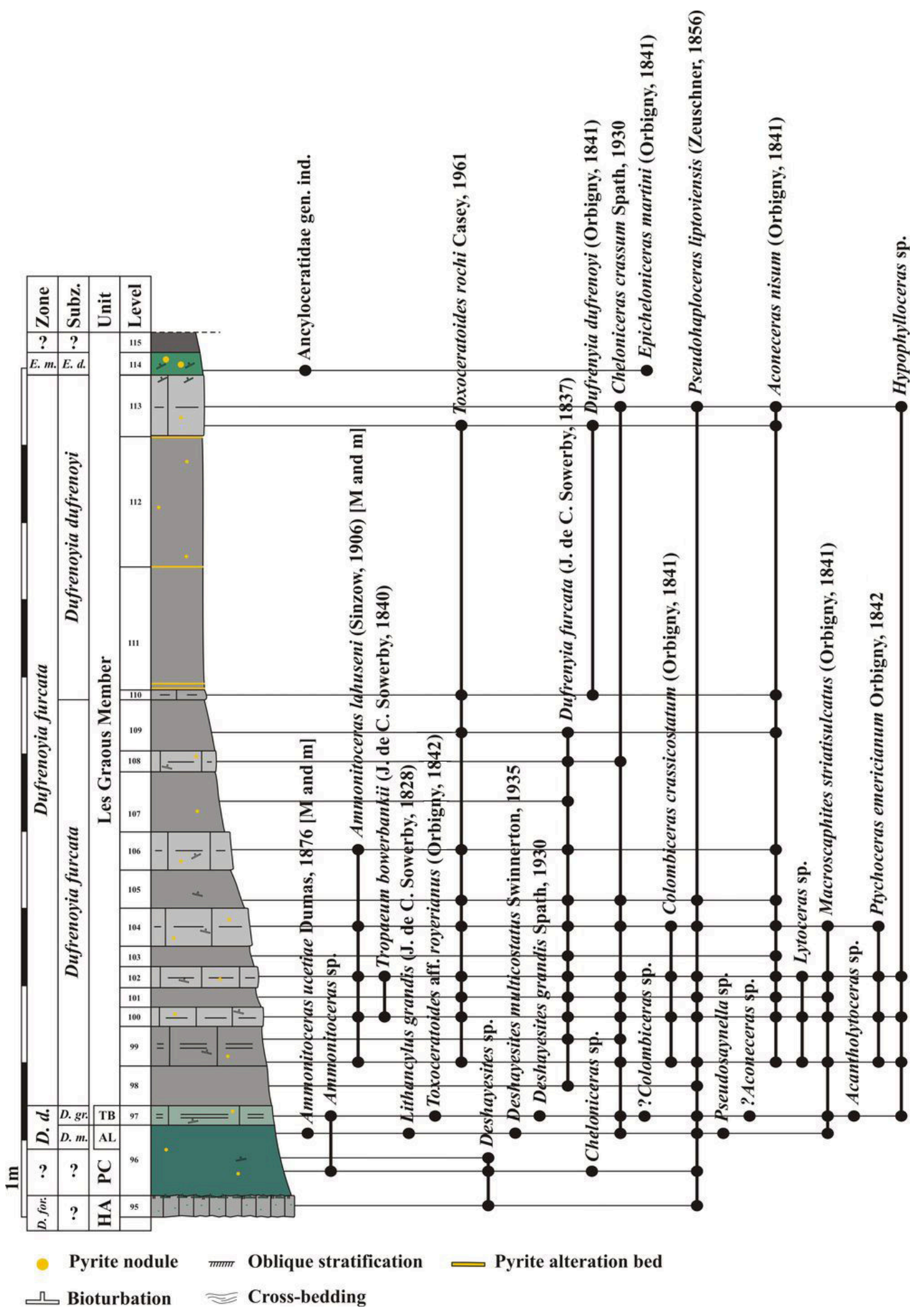

Figure 5: Log of the Les Graous 1 section (GRS 1) with distribution of the ammonite taxa, see Fig. 4 for caption. HA: Hauterivian-Aptian limestones. PC: Pont de la Cerise Member. D. for.: Deshayesites forbesi. D. d.: Deshayesites deshayesi. D. m.: Deshayesites multicostatus. D. gr.: Deshayesites grandis. E. m.: Epicheloniceras martini. E. d.: Epicheloniceras debile. [M]: macroconch, [m]: microconch. 

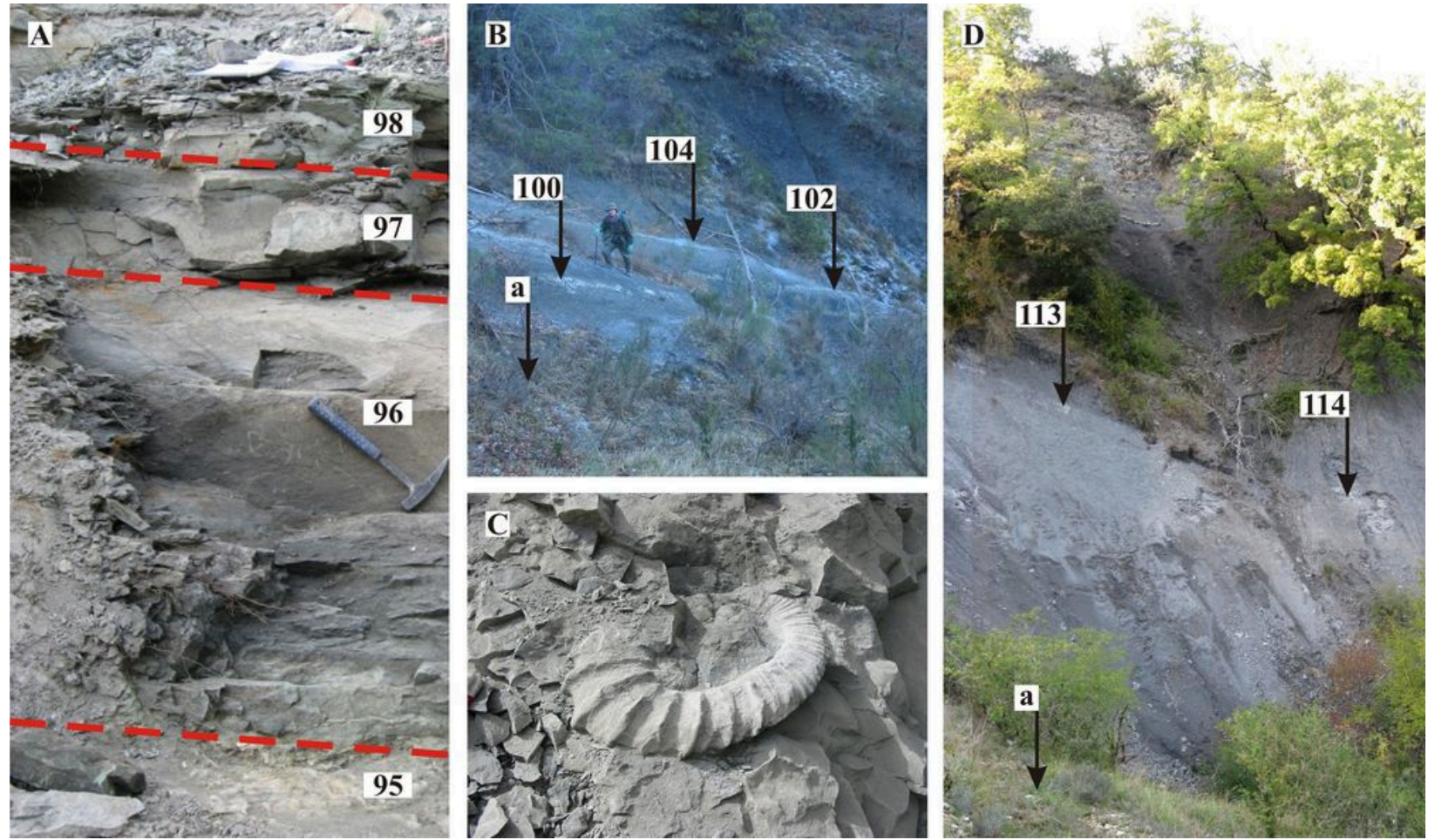

Figure 6: Field photographies of the Les Graous 1 section (GRS 1). Log of this section is figured in Fig. 5. A: Beds 95 to 98 at the base of the section in 2009. Length of the hammer: $330 \mathrm{~mm}$. B: Beds 100 to 104 in the lower part of the Les Graous Member in 2005. C: specimen No. 28750, holotype of Caseyites morenobedmari DeLANoY et al., 2018 (DELANOY et al., 2018, Fig. 15, = Ammonitoceras lahuseni (SinZOW, 1906) [m] in Fig. 5) during extraction from Bed 102 of GRS 1 in 2006. Length of the ammonite: $468 \mathrm{~mm}$ (DELANOY et al., 2018, p. 63). D: lower Aptian deposits of GRS 1, overlain by upper Aptian and Albian in 2010; a: top of the Hauterivian-Aptian limestones.

sp., Procheloniceras sp., Pseudohaploceras sp., Costidiscus recticostatus (ORBIGNY, 1841). We identified: Ancyloceras rochi SARKAR, 1955 (PI. 1, figs. 1-2), Ancyloceras sp. (PI. 1, fig. 3), Toxoceratoides sp., Deshayesites sp. (PI. 1, figs. 4-5), Procheloniceras sp. (PI. 1, figs. 6-7), Pseudohaploceras sp. (PI. 1, fig. 8), Pseudohaploceras liptoviensis, Hypophylloceras sp. This fauna is associated with numerous nautiloids [Cymatoceras neckerianus (PICTET, 1847) (PI. 1, fig. 9)] and belemnites (Mesohibolites sp.).

We could not identify any Deshayesites from this bed at the specific rank because the characteristics of their ventral area in the inner whorls and their suture line could not be observed (BERSAC \& BERT, 2012, 2015). Nevertheless, their rounded ventral areas on the phragmocone suggests that they are older than the $D$. grandis Subzone (PI. 1, fig. 5).

The Douvilleiceratidae collected in this bed have a relatively long and well expressed Procheloniceras stage and no Cheloniceras stage was observed (BERSAC \& BERT, 2018), but the innermost whorls of the studied specimens are not preserved: if the Cheloniceras stage occurs, it is restricted to innermost whorls only (PI. 1, figs. 6-7). The shape of these specimens with more primitive features than Cheloniceras cornuelianum (ORBIGNY, 1841) leads us to attribute them to the genus Procheloniceras SPATH, 1923. This genus seems to occur at the top of the $D$. forbesi Zone (sensu BERSAC et al., 2012), whereas the genus Cheloniceras succeeds it from the base of the $D$. deshayesi Zone (BERSAC \& BERT, 2018). It should be noted that we have not collected any representative of the stratigraphically significant family Roloboceratinae CASEY, 1961. Their representatives occur in the lower part of the $D$. forbesi Zone (sensu BERSAC et al., 2012) in the Boreal realm and at least from the upper part of the $D$. forbesi Zone or from the base of the $D$. deshayesi Zone (sensu BERSAC et al., 2012) in the Tethysian realm (CASEY et al., 1998; BERSAC \& BERT, 2012, Fig. 17, 2015, Fig. 15).

Small Ancyloceras ORBIGNY, 1842, similar to those collected at the top of the Hauterivian-Aptian limestones, were reported in the Deshayesites weissi Zone ( $=D$. forbesi Zone sensu REBOULET et al., 2018) by Ropolo et al. (1998, p. 171) in the Roquefort-la Bédoule area (SE France); they were identified as Ancyloceras matheronianum ORBIGNY, 1842. Pierre ROPOLO provided photographs of these specimens to us and, from our point of view, they are similar to the type specimen of Ancyloceras rochi, originally described and figured by $\mathrm{RoCH}$ (1927, p. 29, PI. IV, fig. 2) as "Ancyloceras Binelli ASTIER".

Based on these considerations, the last Hauterivian-Aptian limestone bed of the LFAB probably belongs to the lower part of the $D$. forbesi Zone sensu BERSAC et al. (2012; Fig. 1). 


\subsubsection{The Les Graous Formation}

This formation is formally defined for the first time in the present work (Fig. 4) and is restricted to the LFAB. It is represented by dark green glauconitic sandstones in its lower part and grey-blue marls in its upper part. Its lower limit is the terminal discontinuity of the Hauterivian-Aptian limestones. Its upper limit is located at the top of a marly-limestone level just below a dark grey glauconitic level (Fig. 4). This glauconitic level yielded the oldest Epicheloniceras martini (ORBIGNY, 1842) of the study area and was therefore assigned to the upper Aptian Epicheloniceras debile Subzone (Epicheloniceras martini Zone, see DuTour, 2005 and Fig. 1). The Les Graous Formation type section is Les Graous 1 (GRS1, Figs. 3, 5 6, and see Chapter 5.3.1), where it is observable in its entirety. The Les Graous Formation is the equivalent of Cotillon's (1971, p. 69) formations $a b 1$ and $a b 2$ of the neritic domain of the Castellane Arc. At Les Ferres, this author (ibid., p. 146) named it "[a, b]".

We propose to divide the Les Graous Formation into several lithostratigraphic members, described here for the first time:

\subsubsection{The Combe de Joinet Member}

This lithostratigraphic unit is restricted to the LFAB (Fig. 4). It was previously mentioned by RAGAZZI (1982, p. 76), who named it "marnes bleutées" ("bluish marls").

The Combe de Joinet Member is represented by $1.10-1.50 \mathrm{~m}$ of light grey marly limestone in which are sometimes intercalated two more indurated decimetric levels or a glauconitic decimetric level. The lower limit of this member is the discontinuity surface at the top of the Hauterivian-Aptian limestones. Its upper limit is an intensely bioturbated discontinuity surface (ichnogenus Thalassinoides EHRENBERG, 1944; Fig. 13.B). The type section of this member is the Combe de Joinet section (CHP, Figs. 3, 10 11, and see Chapter 5.3.4). The ammonite fauna of the Combe de Joinet Member is particularly rare and only represented by fragmented internal moulds of Ancyloceras sp., Deshayesites sp., Cheloniceras crassum, Macroscaphites aff. yvani, Pseudohaploceras liptoviensis and Pseudohaploceras sp. This member crops out in the following sections: La Vallière (VAL, see Figs. 3, 7 - 8, and Chapter 5.3.2), Combe de Joinet (CHP), Pont de la Cerise (CLE, see Figs. 3, 12 - 13, and Chapter 5.3.5) and Combe de Marin (CRS, see Figs. 3, 14, and Chapter 5.3.6). It also partly crops out in the Pont Païré section (PPR, see Figs. 3, 15 - 16, and Chapter 5.3.7).

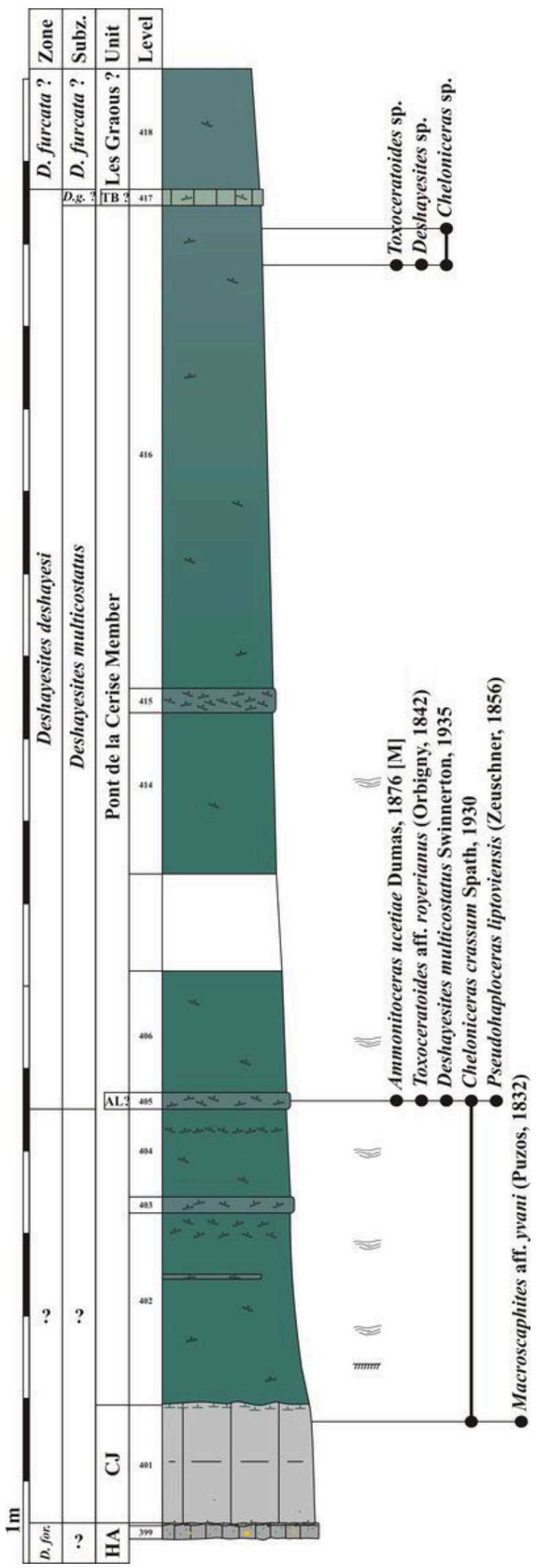

Figure 7: Log of the La Vallière section (VAL) with distribution of ammonite taxa, see Figs. 4 - 5 for caption. 

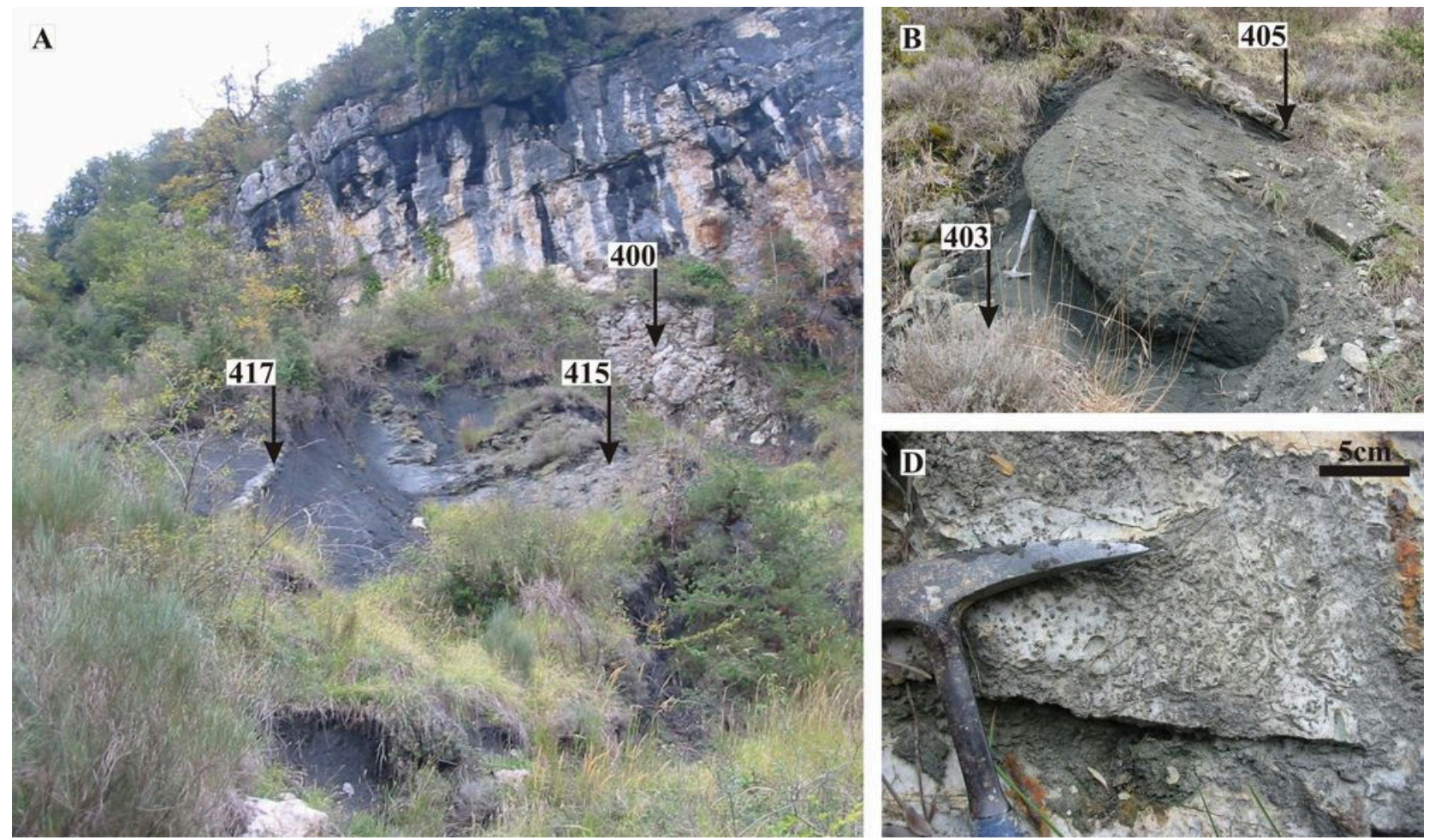

Figure 8: Field photographies of the La Vallière section (VAL). Log of this section is figured in Fig. 7. A: general view (2004) of the upper part of the section, located against a palaeo-escarpment. B: Beds 403 to 405 of the Pont de la Cerise Member in 2010. Bed 405 is interpreted to be the local equivalent of the Ammonitoceras Level. 8.C: upper surface of the last bed (400) of the Hauterivian-Aptian limestones with Rhizocorallium.

\subsubsection{The Pont de la Cerise Member}

This member is restricted to the LFAB (Fig. 4) and is represented by massive glauconitic sandstones (RAGAZZI, 1982; BRÉHERET, 1997) in which are often intercalated more or less continuous light grey decimetric beds (Figs. 8.A-B, 16.A). The thickness of this member varies from less than one metre in the Les Graous 1 section (GRS1) to $15 \mathrm{~m}$ in the La Vallière section (VAL, Fig. 17). The lower limit of this member is represented by the discontinuity surface at the top of the underlying Combe de Joinet Member. Its upper limit is characterized by the abrupt end of the glauconitic sandstones, which are overlain by a characteristic, more or less marly, grey limestone bed, here named the "Toxoceratoides Bed" (which belongs to the overlying Les Graous Member, see Chapter 5.2.2.3). The type section of the Pont de la Cerise Member is at the Pont de la Cerise section (CLE, see Figs. 3, 12 - 13, and Chapter 5.3.5). The first decimetres of this member are relatively rich in phosphate nodules, belemnite fragments and fish teeth. When this member reaches a plurimetric thickness, the first two meters display cross-stratifications. Bioturbation is frequent throughout the Pont de la Cerise Member, especially in the more indurated levels (Figs. 5 - 16, Thalassinoides in Fig. 13.C).
The glauconitic sandstones of the Pont de la Cerise Member were first mentioned by Goguel (1944, p. 21) who assigned them to the Albian. GINSBURG et al. (1980) and RAGAZZI (1982, p. 74) dated them as Aptian. A level remarkably rich in ammonites generally occurs in the upper $0.5 \mathrm{~m}$ of this member. It is named here the "Ammonitoceras Level" and will be described below. The Pont de la Cerise Member crops out in the following sections: Les Graous 1 (GRS1), Les Graous 2 (GRS2), La Vallière (VAL), Combe de Joinet (CHP), Pont de la Cerise (CLE), Combe de Marin (CRS), and Pont Païré (PPR).

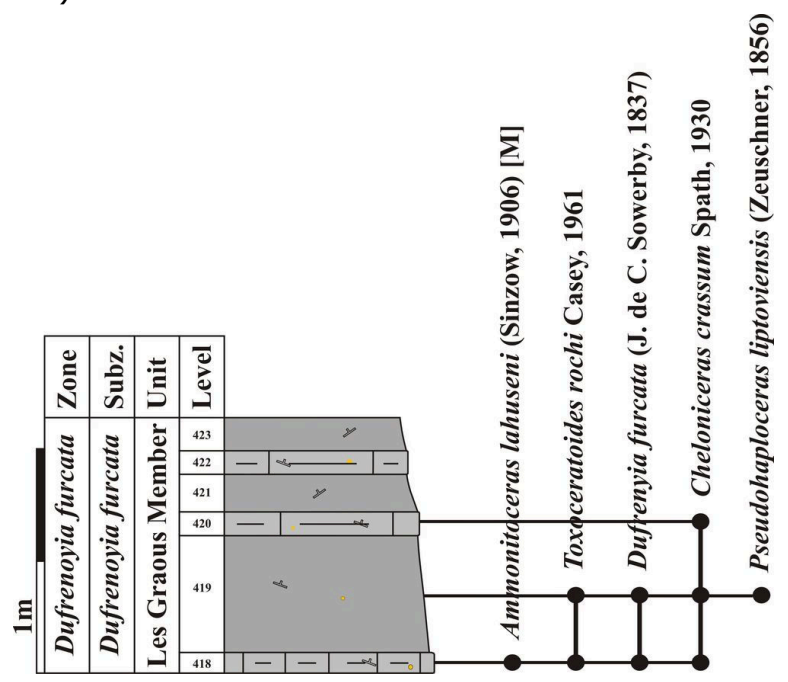

Figure 9: Log of the La Graou section (GRO) with distribution of ammonite taxa, see Fig. 5 for caption. 


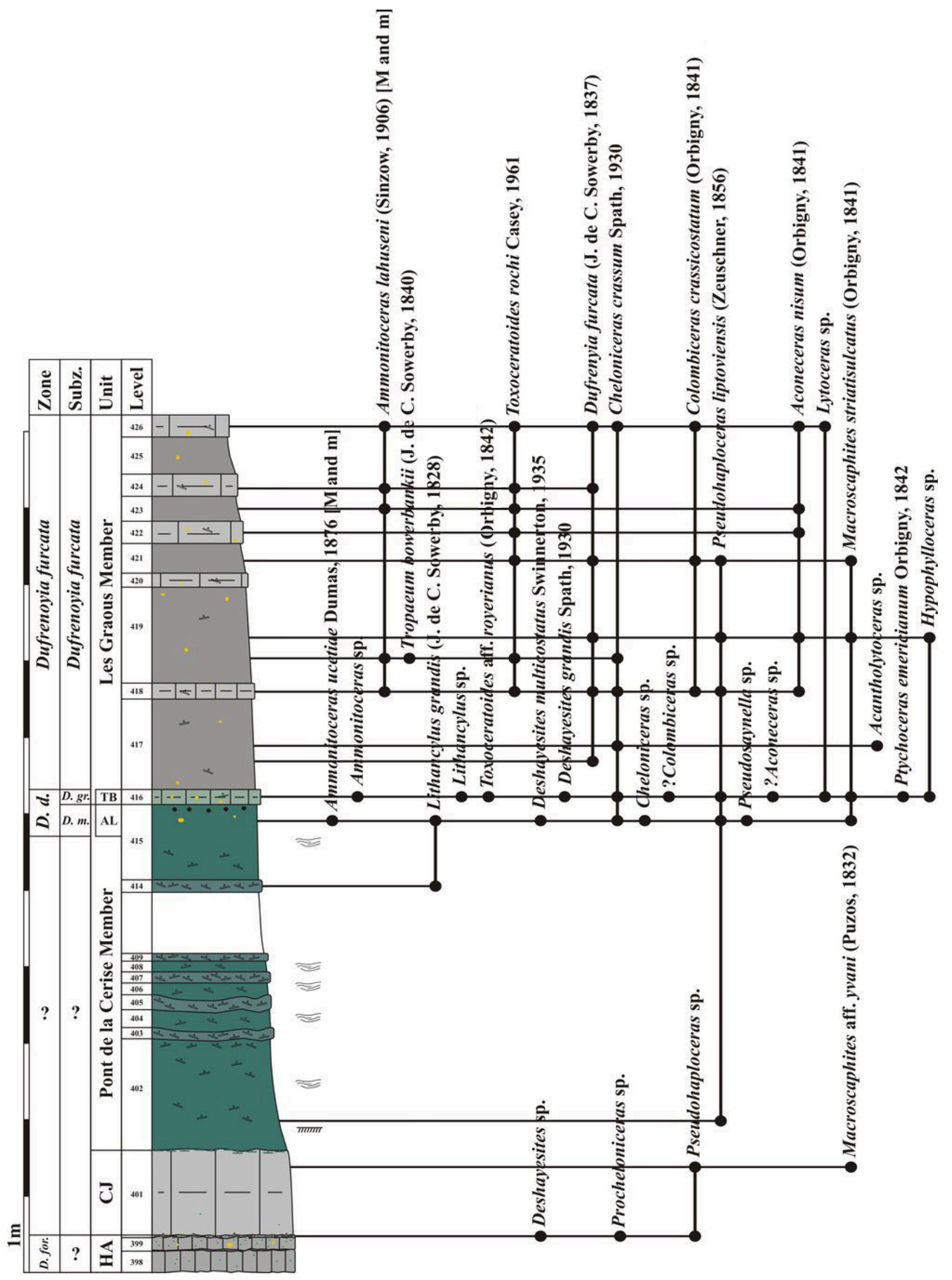

Figure 10: Log of the Combe de Joinet section (CHP) with distribution of ammonite taxa, see Figs. 4 - 5 for caption. 

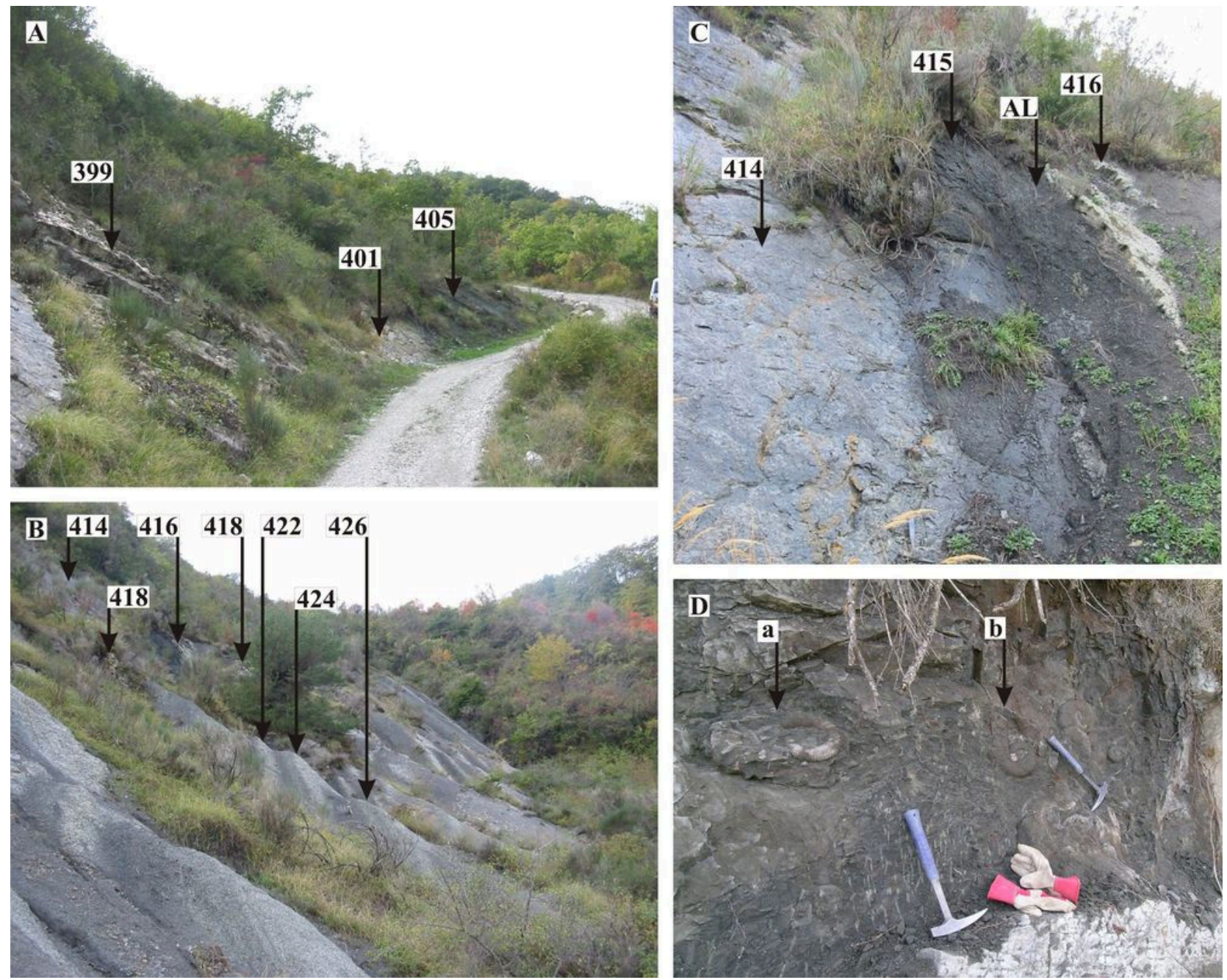

Figure 11: Field photographs of the Combe de Joinet section (CHP). Log of this section is figured Fig. 10. A: top of the Hauterivian-Aptian limestones and lower part of the section in 2004. B-C: top of the Pont de la Cerise Member and lower part of the Les Graous Member in 2004. AL: Ammonitoceras Level. D: ammonites in situ in the Ammonitoceras Level in 2009 (refigured from BERT, 2014, p. 393). a: specimen No. "28769" identified as Caseyites esteronensis DeLANOY et al., 2018 in DeLANOY et al. (2018, p. 58, Fig. 12.A-B), quoted as Ammonitoceras ucetiae DUMAS, 1876 [m] in Fig. 10. b: specimen No. AP-001, holotype of Pseudocrioceras bournaudi DeLANoY et al., 2018 in DELANOY et al. (2018, p. 47, Figs. 7, 8.A), quoted as Ammonitoceras ucetiae DumAS, 1876 [m] in Fig. 10. Length of the hammer: $330 \mathrm{~mm}$.

Apart from the Ammonitoceras Level, the ammonite fauna of the Pont de la Cerise Member is represented by rare and poorly preserved internal moulds (Fig. 13.D). We recognized the following taxa: Ammonitoceras sp., Lithancylus grandis, Deshayesites sp. Cheloniceras sp., Pseudohaploceras liptoviensis and a fragmentary Ancyloceratidae unidentifiable at the generic rank. Belemnites are represented by Neohibolites aptiensis (STOLLEY, 1913) and Duvalia grasi (DUVAL-JOUVE, 1841). A level one centimetre above the Ammonitoceras Level yielded small internal phosphate moulds of Macroscaphites striatisulcatus and Pseudohaploceras liptoviensis.

The Ammonitoceras Level is a 0.20 m-thick level particularly rich in ammonites. It is located approximately $0.50 \mathrm{~m}$ below the upper limit of the Pont de la Cerise Member (Figs. 4, 11.C-D).
This level provided an abundant cephalopod fauna mainly consisting of deformed internal moulds of ammonites and nautiloids, and belemnite rostra (PI. 2, figs. 1-17, 19-20). The proportion of subcomplete representatives of the heteromorphic ammonite family Ancyloceratidae, especially Ammonitoceras, is noteworthy (Fig. 11.D ; PI. 2, figs. 1-5). The type section of this reference level is the Combe de Joinet section (CHP) where it crops out under particularly favourable conditions (see Chapter 5.3.4). Heteromorph ammonites are deposited without preferential orientation (Fig. 11.D). BERT (2014, p. 393) figured this level for the first time (Fig. 11.D), and Delanoy et al. (2018) described and figured many ammonites. We identified the following taxa in the Ammonitoceras Level: Ammonitoceras ucetiae macroconchs (PI. 2, figs. 1-2) and microconchs (PI. 2, figs. 3-5), Lithancylus grandis (PI. 2, figs. 11-12), Deshayesites multicostatus (PI. 


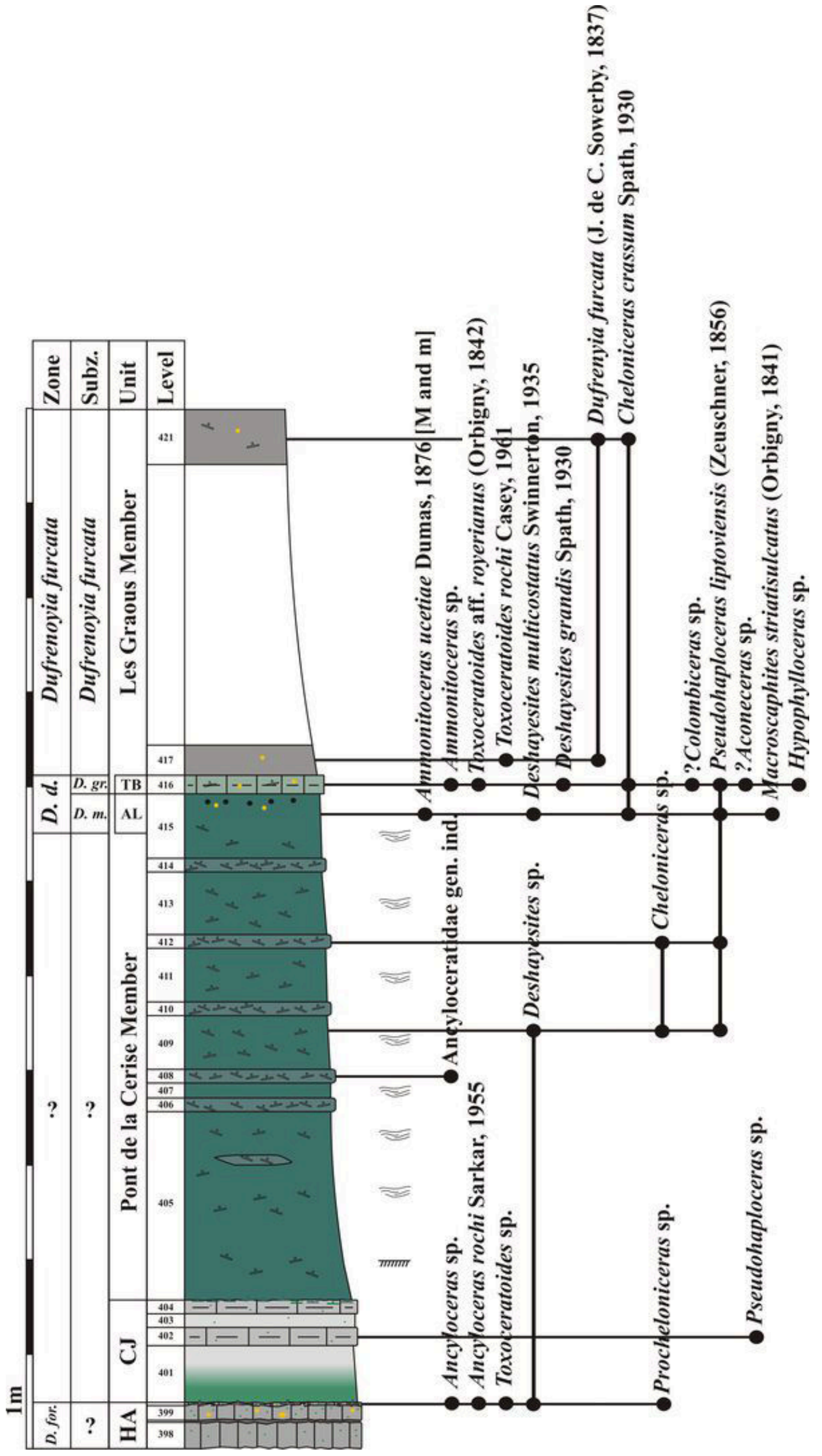

Figure 12: Log of the Pont de la Cerise section (CLE) with distribution of ammonite taxa, see Figs. 4 - 5 for caption. 

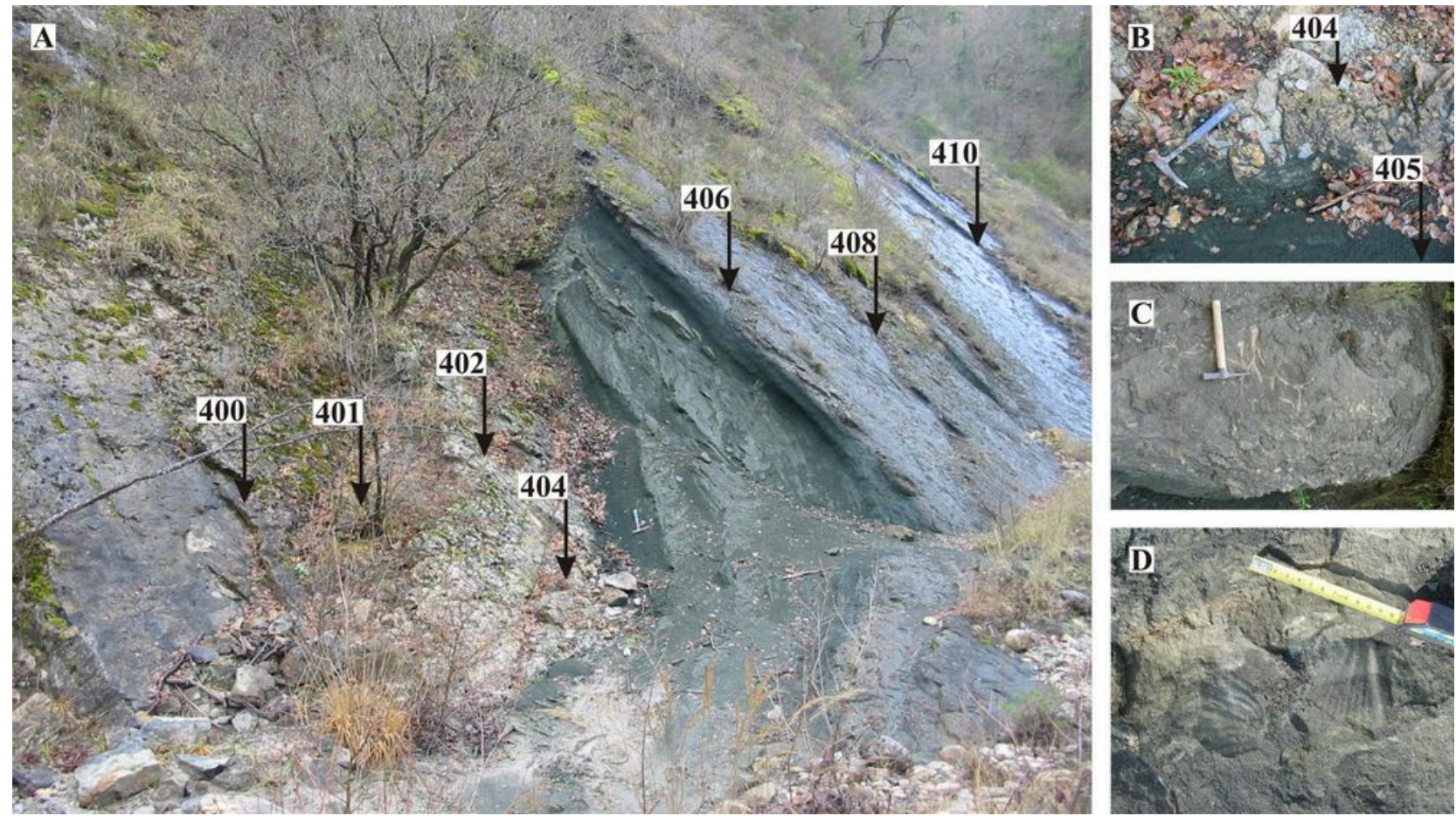

Figure 13: Field photographs of the Pont de la Cerise section (CLE). Log of this section is available in Fig. 12. A: top of the Hauterivian-Aptian limestones, Combe de Joinet Member and Pont de la Cerise Member in 2004. B: Thalassinoides at the top of the Combe de Joinet Member (bed 404) in 2004. Length of the hammer: 330 mm. C: Thalassinoides in Bed 408 of the Pont de la Cerise Member. Length of the hammer: $290 \mathrm{~mm}$. D: ammonites fragments in Bed 409 (Cheloniceras sp. and Pseudohaploceras sp. in Fig. 12). Tape measure with centimetre markings.

2, figs. 6-8, 13-15, 19), Cheloniceras crassum (PI. 2, figs. 16-17), Cheloniceras sp., Pseudohaploceras liptoviensis (PI. 2, figs. 9-10), Pseudosaynella sp., Macroscaphites striatisulcatus (PI. 2, fig. 20). Belemnites are represented by $\mathrm{NeO}-$ hibolites aptiensis and Duvalia grasi. Nautiloids are frequent and represented by Cymatoceras neckerianus, Eucymatoceras plicatum (FITTON, 1836) and Anglonautilus sp. The level 405 of the La Valliere section (VAL) is a possible local representative of the Ammonitoceras Level (see Chapter 5.3.2) and additionally provided Toxoceratoides aff. royerianus. Gastropods, bivalves and ahermatypic corals are relatively rare (PI. 2, fig. 18).

Deshayesitidae of the Ammonitoceras Level have a smooth siphonal band ending at a diameter between 15 and $18 \mathrm{~mm}$ and their ventral area is not subtabulated on the phragmocone (PI. 2, figs. 8, 14). These characters correspond to the index species D. multicostatus (BERSAC \& BERT, 2015). The genus Cheloniceras is represented by two distinct morphologies:

1. a relatively frequent one, characterized by a long Cheloniceras stage and a short ProcheIoniceras stage. The "intermediate stage" of Cheloniceras parinodum CASEY, 1961, is present in some specimens between the Cheloniceras and Procheloniceras stages (BERSAC \& BERT, 2018). For these reasons, we attributed this morphology to a primitive form of C. crassum (PI. 2, figs. 16-17);

2. a much rarer second morphology, with evolute coiling and with relatively short Cheloniceras stage. This form we left in open nomenclature, resembles the primitive parahoplitid Colombiceras and could be its ancestor.

The presence of $D$. multicostatus and C. crassum with primitive morphology in the Ammonitoceras Level indicates an age corresponding to the late part of the $D$. multicostus Subzone ( $D$. deshayesi Zone) sensu BERSAC et al. (2012; Fig. 1). The morphology of the Ammonitoceras in the Ammonitoceras Level, with a short Ammonitoceras ontogenetic stage and an important spiral hiatus in macroconchs (PI. 2, fig. 1), is consistent with such an age.

The absence of Deshayesites bearing a longer smooth siphonal band and a subtabulated ventral area on the phragmocone (corresponding to the index species $D$. grandis, see BERSAC \& BERT, 2012), allows us to exclude the presence of the $D$. grandis Sub-zone in the Ammonitoceras Level.

The Ammonitoceras Level crops out in the following sections: Les Graous 1 (GRS1), Les Graous 2 (GRS2), La Vallière (VAL), Combe de Joinet (CHP), Pont de la Cerise (CLE) and Pont Païré (PPR). 


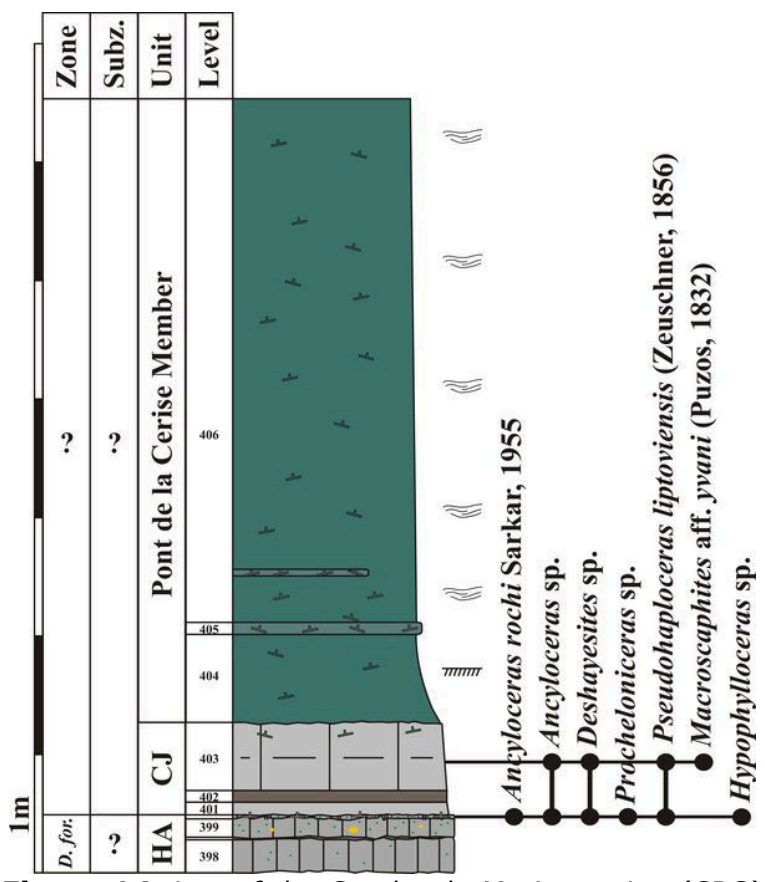

Figure 14: Log of the Combe de Marin section (CRS) with distribution of ammonite taxa, see Figs. 4 - 5 for caption.

\subsubsection{The Les Graous Member}

This member is restricted to the LFAB (Fig. 4 ). It starts with a marly limestone level of about $0.2 \mathrm{~m}$ thickness, named here the Toxoceratoides Bed (Figs. 4, 11.C). The type section of the Les Graous Member is at the Les Graous 1 section (GRS1).

The levels of the Les Graous Member above the Toxoceratoides Bed are represented in the sections at Les Graous 1 (GRS1) and Les Graous 2 (GRS2) by blue-grey sandy marls. A bundle of 6 more indurated beds is intercalated in the lower part of these marls (Figs. 6.B, 11.C-D). Within the Les Graous Member, pyrite nodules and centimetre-thick pyrite alteration beds are relatively common. The upper limit of this member can only be observed at the GRS 1 and GRS 2 sections: it corresponds to a discontinuity surface with numerous Thalassinoides located at the top of a 0.80 m-thick marly limestone bed (GRS 1 and GRS 2 bed 113; Figs. 5, 6.D).

The Toxoceratoides Bed provided a large number of deformed internal moulds of ammonites, nautiloids, belemnites (PI. 3, figs. 7-8), bivalves, gastropods, corals, and fish scales. The ammonite fauna is represented by Ammonitoceras sp., Lithancylus sp., Toxoceratoides aff. royerianus (PI. 3, figs. 13-16), Deshayesites grandis (PI. 3, figs. 9-12), Cheloniceras crassum (PI. 3, figs. 5-6), ?Colombiceras sp., Pseudohaploceras liptoviensis, ?Aconeceras sp., Macroscaphites striatisulcatus (PI. 3, figs. 3-4), Acantholytoceras sp., Ptychoceras emericianum, Hypophylloceras sp. (PI. 3, fig. 1) and Lytoceras sp.

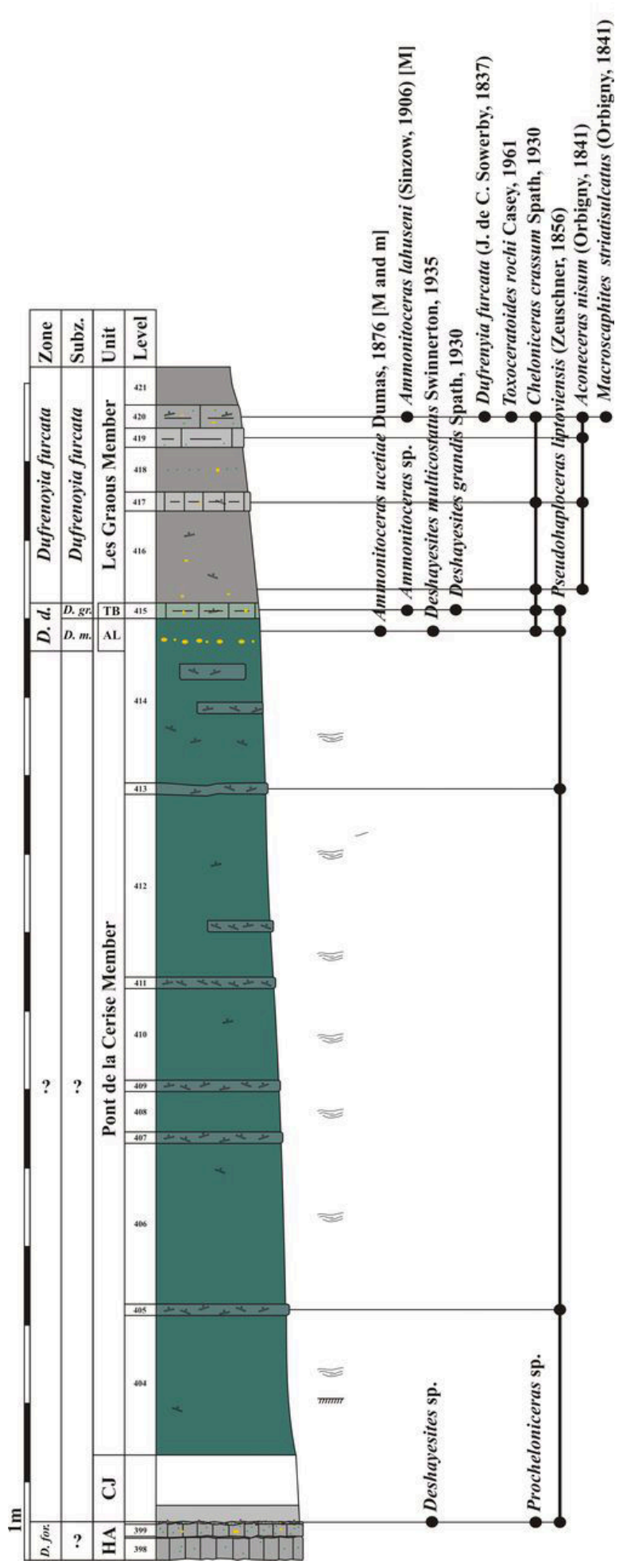

Figure 15: Log of the Pont Païré section (PPR) with distribution of ammonite taxa, see Figs. 4 - 5 for caption.

The Deshayesites in this level have a well-expressed smooth siphonal band and a subtabulated ventral area on the phragmocone (PI. 3, figs. 9, 12). The Cheloniceras have a long Cheloniceras stage and a short or absent Procheloniceras stage (PI. 3, fig. 5). These characters indicate an age corresponding to the $D$. grandis Subzone (Fig. 1). 

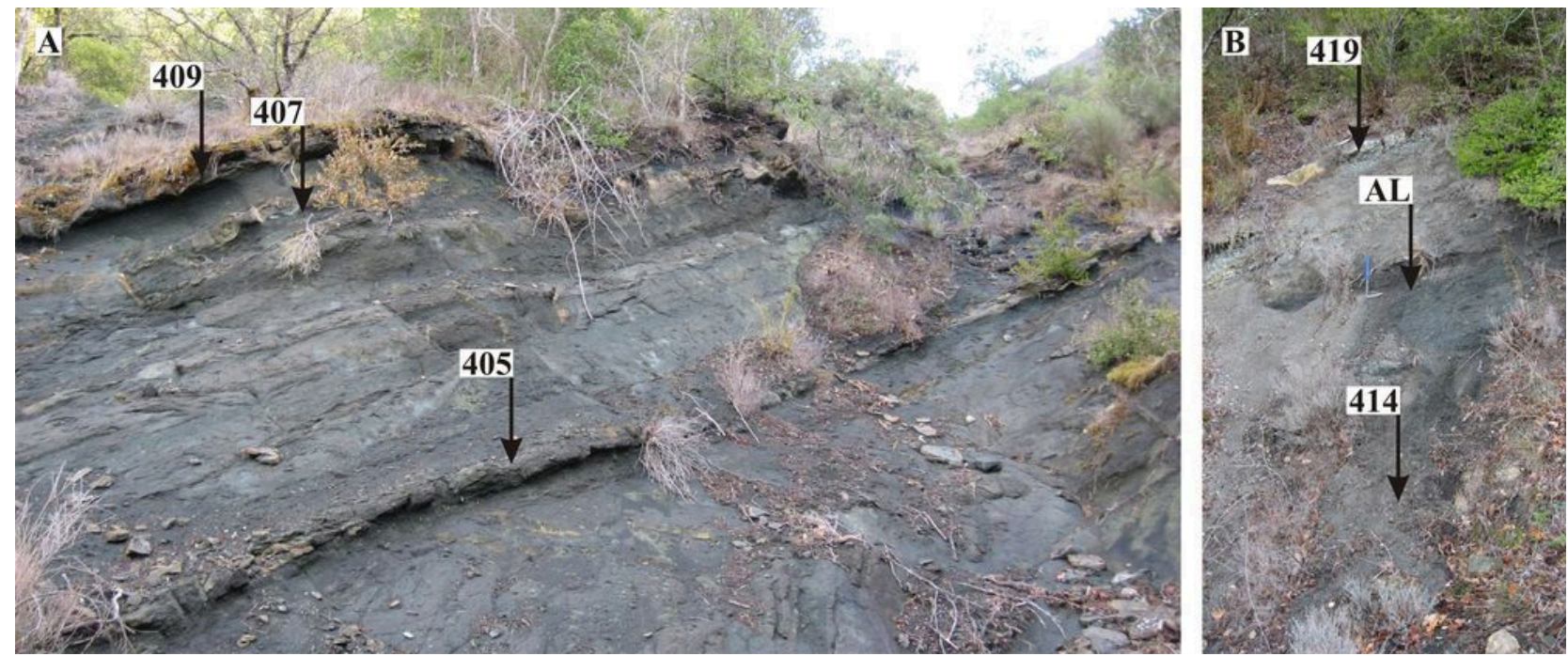

Figure 16: Field photographies of the Pont de la Cerise section (CLE). Log of this section is available in Fig. 15. A: Pont de la Cerise Member in 2017. B: top of the Pont de la Cerise Member and base of the Les Graous Member in 2017. AL: Ammonitoceras Level.

Above the Toxoceratoides Bed, the lower part of the Les Graous Member yielded an abundant ammonite fauna represented by deformed internal moulds (Fig. 6.C). Within these levels, belemnites (PI. 5, figs. 17-21) and fish scales (PI. 5, fig. 26) are relatively frequent. Nautiloids, echinoids (Pl. 5, figs. 27-28), brachiopods (PI. 5, fig. 29), gastropods (PI. 5, figs. 22-23), bivalves (PI. 5, fig. 24) and small ahermatypic corals (PI. 5, fig. 25) are rarer. Fossils are noticeably more frequent in the more indurated beds. Pyritic internal moulds of ammonites are extremely rare and poorly preserved. In the lower part of the grey-blue marls, we identified the following ammonitic taxa: Ammonitoceras lahuseni macroconchs (PI. 4, figs. 1-3) and microconchs, Tropaeum bowerbankii, Toxoceratoides rochi (PI. 5, figs. 1-4), Dufrenoyia furcata (Pl. 5, figs. 5-9), Cheloniceras crassum (PI. 4, figs. 8-9), Colombiceras crassicostatum (PI. 5, figs. 10-12), Pseudohaploceras liptoviensis (PI. 4, figs. 6-7), Aconeceras nisum (PI. 5, figs. 13-14), Ptychoceras emericianum (PI. 5, fig. 15), Macroscaphites striatisulcatus (PI. 5, fig. 16), Acantholytoceras sp. (PI. 4, figs. 4-5), Lytoceras sp. (PI. 4, figs. 10-11), Hypophylloceras sp. (PI. 4, fig. 12). Nautiles are represented by Cymatoceras neckerianus (PI. 4, figs. 13-14) and Anglonautilus $\mathrm{sp}$.

In the upper part of the Les Graous Member, we identified Toxoceratoides rochi, Dufrenoyia dufrenoyi (PI. 5, figs. 30-32), Cheloniceras crassum, Pseudohaploceras liptoviensis, Aconeceras nisum, Hypophylloceras sp.

Belemnite taxa, Neohibolites aptiensis (PI. 5, figs. 17-18), Duvalia grasi (PI. 5, figs. 19-20) and Mesohibolites sp. (PI. 5, fig. 21), occur throughout the Les Graous Member.
The grey-blue marls of the Les Graous Member are assigned to the $D$. furcata Zone (Fig. 1): their lower part is assigned to the $D$. furcata Subzone and their upper part to the $D$. dufrenoyi Subzone.

\subsection{DESCRIPTIONS OF THE STUDIED SECTIONS}

Eight sections were sampled between 2000 and 2017. They are located along an E-W axis on either side of the village of Les Ferres (Fig. 3). These sections are (from $W$ to $E$ ):

\subsubsection{Les Graous sections (GRS1 and GRS2)}

These sections are located about $1.65 \mathrm{~km}$ to the WSW of the village of Les Ferres. Les Graous 1 (GRS 1, Fig. 3, lat.: $43^{\circ} 50^{\prime} 31.8^{\prime \prime} \mathrm{N}$, long.: $7^{\circ} 4^{\prime}$ $35.4 \mathrm{E}$ ) crops out on the eastern flank of the Les Graous cuesta and Les Graous 2 (GRS 2, Fig. 3, lat.: $43^{\circ} 50^{\prime} 31.0^{\prime \prime} \mathrm{N}$, long.: $7^{\circ} 4^{\prime} 27.3^{\prime \prime} \mathrm{E}$ ) on its western flank. Because of their similar lithostratigraphy, the log of GRS 1 only is figured (Fig. 5). Field photographs and log section of GRS 1 were given by BERT \& BERSAC (2011, Figs. 30, 32-37, 4047 ), but the exact location of this section was not indicated because fieldwork had not been completed then. In this section, the marly Aptian can be observed continuously from the top of the Hauterivian-Aptian limestones to the Albian (Fig. 6.B, .D). The Combe de Joinet Member is absent and the Pont de la Cerise Member lies directly on the Hauterivian-Aptian limestones. The Pont de la Cerise Member is only $0.90 \mathrm{~m}$ thick in GRS 1 (Figs. 5, 6.A). A bed of phosphate nodules can be observed at $15 \mathrm{~cm}$ above its base. At the top of this member the Ammonitoceras Level provided some poorly preserved ammonite fragments. In addition to the ammonite taxa cited in Fig. 5, the Pont de la Cerise Member provided Cymatoceras neckerianus $(20 \mathrm{~cm}$ above its base), Anglonautilus sp. ( $30 \mathrm{~cm}$ above its base) and several specimens of Neohibolites aptiensis. 
The Toxoceratoides Bed is present at the base of Les Graous Member (Figs. 5, 6.A). It is relatively marly here and yielded a fairly abundant fauna of ammonites, belemnites and nautiloids. Above the Toxoceratoides Bed, the first 5 metres of this member are represented by a bundle of 6 sandy and marly limestone beds separated from each other by marly intervals (Figs. 5, 6.B). A rich ammonite fauna assigned to the D. furcata Subzone (Fig. 6.C ; PI. 4, figs. 8-12; PI. 5, figs. 1-16) was collected mainly from the first 5 sandy and marly limestone beds and Bed 99 (Fig. 5).

The upper part of the Les Graous Member is attributed to the $D$. dufrenoyi Subzone. It is marlier and only the sandy and marly limestone beds yielded ammonites. Bed 110 yielded the earliest $D$. dufrenoyi (Fig. 5). The upper limit of this member is represented by a sandy limestone bed (Bed 113, Fig. 5) that is relatively rich in ammonites (especially in $D$. dufrenoyi, PI. 5, fig. 32). It is overlain by upper Aptian dark glauconitic marls. All the material from "les Graoux" published by Delanoy et al. (2018) was collected from Beds 99, 100 and 102 of the GRS 1 section in our presence.

\subsubsection{La Vallière section (VAL)}

RAGAZZI (1982, p. 73) and BRÉHERET (1997, p. 267, Figs. 114-115) studied a section located in the La Vallière area (Fig. 3, lat.: 4350'32.6"N, long.: 705'29.9"E). This section is nowadays almost completely covered by vegetation and located in a private fenced property.

We studied an outcrop near this section (VAL section, Figs. 3, 7, lat.: 43०50'32.1"N, long.: $\left.7^{\circ} 5^{\prime} 48.4^{\prime \prime E}\right)$. It is located in a half-graben, against a vertical decametric palaeo-escarpment, about $0.6 \mathrm{~km} \mathrm{SSW}$ of the village of Les Ferres (Fig. 8.A). A cross-section of this tectonic structure was figured by DARDEAU \& GRACIANSKY (1987, Figs. 1-2). In this outcrop, the Pont de la Cerise Member reaches its maximum thickness $(15 \mathrm{~m})$ and is overlain by a $0.2 \mathrm{~m}$ thick sandstone level (Bed 417, Fig. 7), which is the probable local equivalent of the Toxoceratoides Bed (Fig. 8.A). Bed 405, located at $3.70 \mathrm{~m}$ from the base of the Pont de la Cerise Member (Figs. 7, 8.B), yielded a relatively abundant, but fragmentary, ammonite fauna very similar to that of the Ammonitoceras Level. A level located at the top of the Pont de la Cerise Member (top of Level 416, Fig. 7) yielded rare representatives of Toxoceratoides, Deshayesites and Cheloniceras, but they are too fragmentary to be identified to specific level. Nevertheless, the lithological and palaeontological characteristics of this last bed are not equivallent to the Ammonitoceras Level. For this reason, we consider Bed 405 as a local equivalent of the Ammonitoceras Level. This all implies that the glauconitic sandstones over- lying the Ammonitoceras Level of VAL are therefore considerably more developed here than in other sections (Fig. 17). The Les Graous Member of VAL is almost completely covered by vegetation and thus could not be studied.

\subsubsection{La Graou section (GRO)}

The La Graou section (GRO, lat.: 4350'36.2"N, long.: 7०6'0.0"E) was described by RAGAzZI (1982, p. 73), then by BRÉHERET (1997, p. 264, Fig. 114). It is located $0.5 \mathrm{~km} \mathrm{SW}$ to the village of Les Ferres (Figs. 3, 9). The Lower Aptian is nowadays almost totally covered by vegetation and only a small part of the Les Graous Member can be observed.

\subsubsection{The Combe de Joinet section (CHP)}

The CHP section (lat.: 43०50'42.7" $\mathrm{N}$, long.: $7^{\circ} 6^{\prime} 9.5^{\prime \prime E}$ ) is located $0.8 \mathrm{~km}$ ESE of the village of Les Ferres, along a track leading to the Pont de la Cerise Figs. 3, 10 - 11). BERT (2014, p. 393) figured the Ammonitoceras Level at the CHP section for the first time (Fig. 11.D). Delanoy et al. (2018, Fig. 2) published a log of this section and described and figured many ammonites, mainly from the Ammonitoceras Level (Bed 107 in DeLANOY et al., $2018=$ Bed 415 in the present work, Figs. 10, 11.C-D). Unfortunately, several levels located at the base of the marly Aptian were not figured in the log of DeLANOY et al. (2018, Fig. 2), including the Combe de Joinet Member. For this reason, we did not use the bed numbering system of this latter work for our own log (Fig. 10). At CHP, the Combe de Joinet Member (Bed 401) crops out in good conditions along the track between the D1 road and the Pont de la Cerise (Figs. 3, 11.A). It is represented by massive sandy and marly limestones and provided some rare fragments of ammonite. The Ammonitoceras Level crops out under good conditions, allowing the collecting of abundant ammonites (DELANOY et al., 2018; Fig. 11.C-D ; PI. 2, figs. 1-19). Only the lower part of the Les Graous Member is visible, its upper part being covered with dense vegetation (Fig. 11.B).

\subsubsection{The Pont de la Cerise section (CLE)}

This section (lat.: 4350'42.7"N, long.: $7^{\circ} 6^{\prime}$ 9.5"E) was first published by RAGAZZI (1982, p. 75) who named it "Pont de la Cerise" despite the fact that another section closer to the Pont de la Cerise locality was named "Combe de Marin" by RAGAZZI (1982, p. 77 and Fig. 3; Fig. 3 and see Chapter 5.3.6). The CLE section crops out on the right bank of the Esteron River in the locality of the Clot d'Estéron, $1.95 \mathrm{~km}$ east of the village of Les Ferres (Figs. 3, 12). The top of the Hauterivian-Aptian limestones, the Combe de Joinet and Pont de la Cerise members, as well as the Toxoceratoides Bed crop out under favourable conditions (Fig. 13.A). As RAGAZZI noticed (1982, p. 76), the Combe de Joinet Member (Beds 401 to 404 in CHP) is represented by $1.1 \mathrm{~m}$ of marly limestone and two decimetric limestone beds (Figs. 12, 13.A). The top of this member is intensely bioturbated (Fig. 13.B). The Pont de la Cerise Member crops out in very 


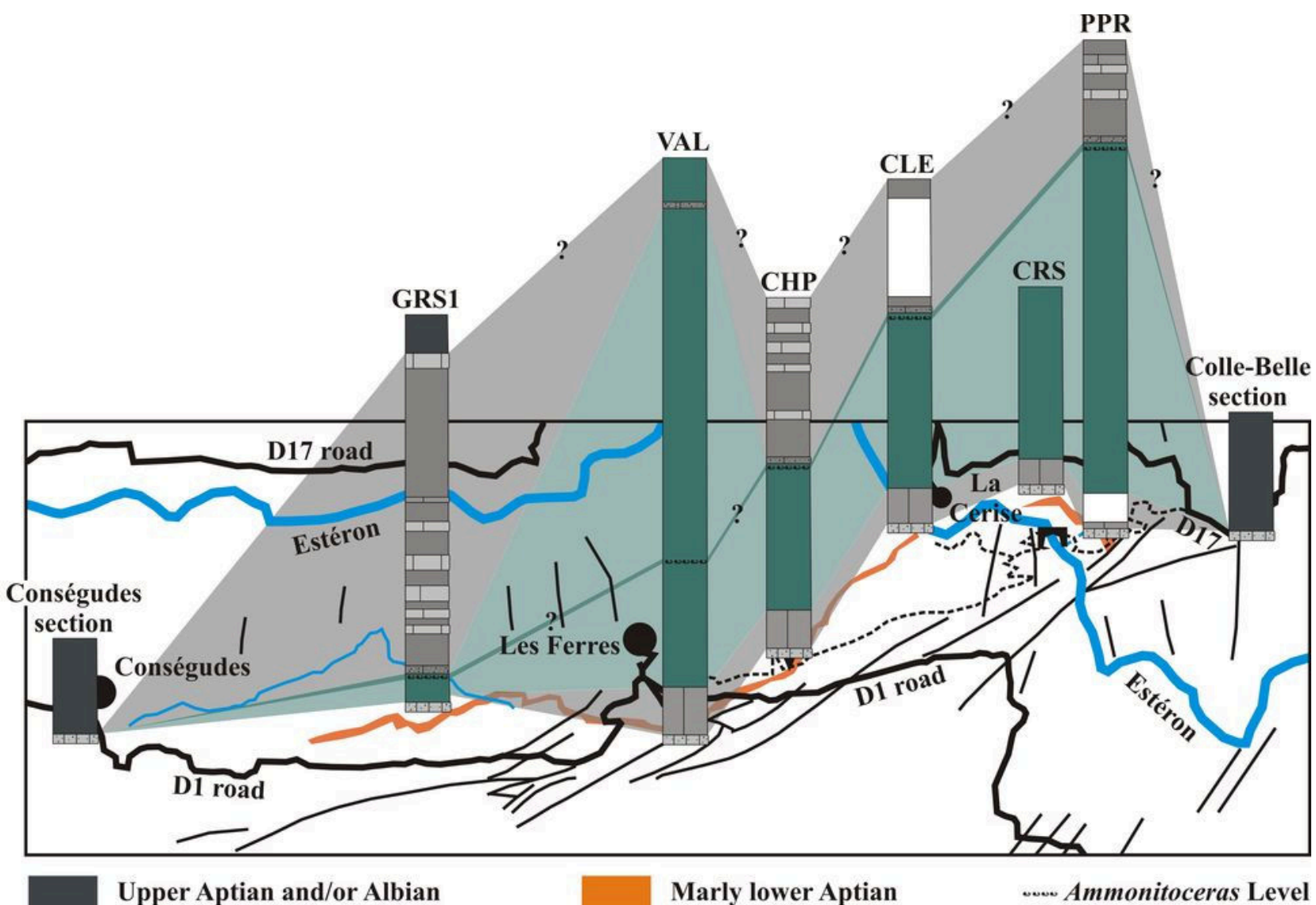

Figure 17: Lithostratigraphic correlation between the studied sections and the adjacent sections.

good conditions and is $5.5 \mathrm{~m}$ thick at that point (Fig. 13.A, .C-D). In its lower and middle parts, rare and poorly preserved fragments of Ancyloceratidae gen. ind., Deshayesites sp., Cheloniceras sp., and Pseudohaploceras liptoviensis (Fig. 13.D) were recorded. The Ammonitoceras Level (Bed 415, Fig. 12) occurs at the top of this member and its ammonite fauna appears to be slightly less abundant and less well-preserved than that at CHP (PI. 2, fig. 20). Only the Toxoceratoides Bed (Bed 416, Fig. 12) of the Les Graous Member crops out under good conditions, the rest of the formation being entirely covered by vegetation.

\subsubsection{The Combe de Marin section (CRS)}

This section was figured by RAGAZZI (1982, p. 77 and Fig. 3). It is located on the left bank of the Esteron River, opposite to the Pont de la Cerise locality, $2.69 \mathrm{~km}$ east of the village of Les Ferres (Fig. 3). The CRS section crops out at the top of a cliff mainly formed by the Hauterivian-Aptian limestones (Fig. 14). Our own observations differ slightly from those of RAGAZZI (1982): only the Combe de Joinet Member and the lower $5.4 \mathrm{~m}$ of the Pont de la Cerise Member are currently observable. The rest of the Aptian marls is covered by vegetation. The Combe de Joinet Member is represented by $0.80 \mathrm{~m}$ of marly limestones, with a dark brown clay level, $0.10 \mathrm{~m}$ thick, in its lower part. The ammonite fauna is rare and fragmen- tary, but includes: Ancyloceras sp., Deshayesites sp., Pseudohaploceras liptoviensis and Macroscaphites aff. yvani.

\subsubsection{The Pont Païré section (PPR)}

RAGAZZI (1982) already mentioned this section ("ravin de Pont de Payre" in Ragazzi, 1982, p. 77) where she observed that the Pont de la Cerise Member was reduced to a thickness of 3.5 metres. This section (lat.: $43^{\circ} 51^{\prime} 11.6^{\prime \prime} \mathrm{N}$, long.: $7^{\circ} 7^{\prime} 49.0^{\prime \prime} \mathrm{E}$, Fig. 15) crops out in a ravine perpendicular to the track between the D17 road and Pont de la Cerise (Fig. 3). Our own observations differ from Ragazzi's (1982): the Pont de la Cerise Member is separated from the Hauterivian-Aptian limestones by a metre-thick covered section and is $11 \mathrm{~m}$-thick (Figs. $15,16 . A-B$ ). This member can be observed under good conditions along the ravine, for a distance of about $100 \mathrm{~m}$. The Ammonitoceras Level (top of Bed 414 in PPR, see Fig. 15) is present at its top (Fig. 16.B), immediately above a level particularly rich in large pyrite nodules. The levels of the Pont de la Cerise Member below the Ammonitoceras Level reach their maximum thickness in this section. Ammonites are very rare in the Pont de la Cerise Member in this section, except in the Ammonitoceras Level. Only the first $3.3 \mathrm{~m}$ of the Les Graous Member are observable (Fig. 16.B); they are richer in glaucony than in the other sections. The Toxoceratoides Bed is marlier than in the CHP and CLE sections, and yielded some ammonites (Figs. 15, 16.B). 


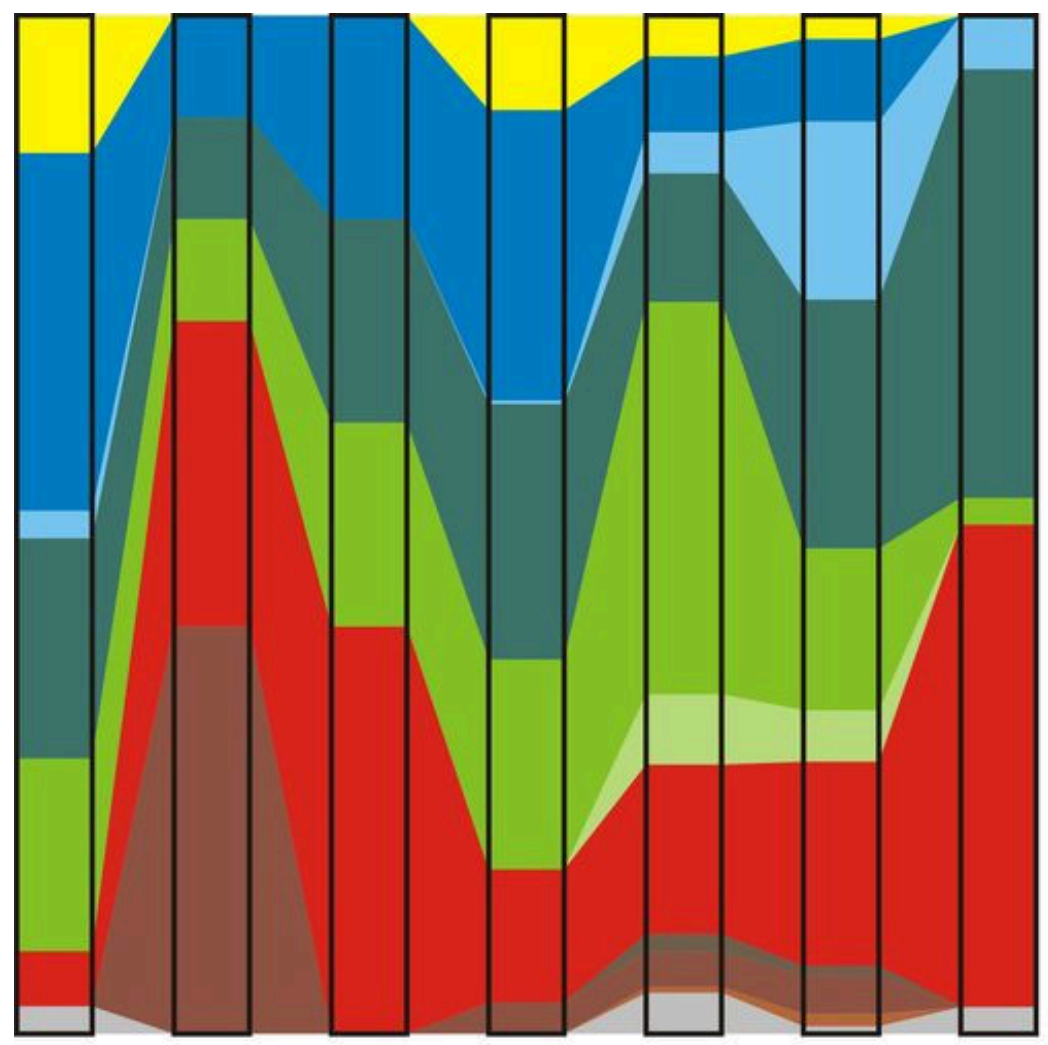

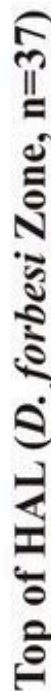

Nautiloidea

Ancyloceratidae

Helicancylidae

Deshayesitidae

Douvilleiceratidae

Parahoplitidae

Desmoceratidae

Lytoceratidae

Macroscaphitidae

Ptychoceratidae

Phylloceratidae

Figure 18: Nautiloidea and Ammonoidea faunal spectrum of the lower Aptian of les Ferres area. HAL: HauterivianAptian limestones, n: number of specimens studied, CJ: Combe de Joinet Member, PC: Pont de la Cerise Member, AL: Ammonitoceras Level, TB: Toxoceratoides Bed, LG: Les Graous Member.

\subsection{LATERAL VARIATIONS OF THE MARLY APTIAN SERIES}

The Combe de Joinet Member appears at $V A L$, where it reaches its maximum thickness (taking into account that this member could not be measured at PPR). It gets thinner towards the east (Fig. 17). The Pont de la Cerise Member appears at GRS 1 and GRS 2 with a thickness of only $0.9 \mathrm{~m}$. The interval of this member beneath the Ammonitoceras Level gradually thicken towards the east (taking into account that we have no thickness data at CRS, Fig. 17) reaching their maximum thickness at PPR. The interval of the Pont de la Cerise Member above the Ammonitoceras Level are generally a few centimeters-thick, except at VAL where they exceptionally reach a thickness of $11 \mathrm{~m}$ (Figs. 7, 8.A, 17). This may be due to the palaeogeographic context of VAL: the presence of a decametric fault palaeoescarpment in this area probably allowed an accumulation of a large amount of sediment above the Ammonitoceras Level (DARDEAU \& GRACIANSKY, 1987). Our observations differ from those of RA- 
GAZZI (1982) who observed a thickness reduction of the Pont de la Cerise Member ("accumulation glauconitique" in RAGAzZI, 1982, p. 78) at CRS and PPR (Fig. 17) compared to more westerly sections. The thickness variation of the Les Graous Member could not be studied because this latter is completely visible only at GRS 1 and GRS 2.

The nearest outcrop west of GRS 2 (Fig. 3) confirms the westward thickness reduction of the Pont de la Cerise Member, as already observed by RAGAZZI (1982). This section, named "Conségudes" by Ragazzi (1982, Fig. 3), crops out along the D1 road next to the village of Conségudes (lat.: 4350'26.5"N, long.: 702' 58.3"E, Fig. 3): the "Early Aptian unconformity" (Cotillon, 2010, p. 4) is located at the top of the upper Barremian limestones and is directly covered by Albian dark marlstones (RAGAZZI, 1982, p. 73 and PI. 3; Fig. 17). The Aptian is therefore totally absent in this section.

East of the study area, the Aptian is also totally missing in the Colle-Belle section (COTILLON, 1971, p. 147, lat.: $43^{\circ} 51^{\prime} 10.4^{\prime \prime} \mathrm{N}$, long.: $7^{\circ}$ 8'32.3"E, Fig. 17), with Albian marlstones lying directly on Barremian limestones (Cotillon, 1971, p. 132 and 147; Fig. 17). The sudden demise of the marly Aptian between the PPR and the Colle-Belle section is probably related to the presence of a decametric synsedimentary fault forming the eastern limit of the LFAB.

North of the study area, Aptian deposits can be observed only on the northern flanks of the Roccaforte and Vial mountains and near the village of Tournefort, where they are represented by plurimetric dark marlstones with pyritized ammonites characteristic of the pelagic domain (RAGAZZI, 1982, p. 61 and personal observations).

To the south, the Aptian is missing or represented in the Coursegoules and Ruth Mountain areas by thin reworked layers (COTILLON, 1971, p. 145; BERSAC et al., 2010; BERT \& BERSAC, 2011, Figs. 4-6, 20, 67-70; BERT et al., 2013, p. 361, Fig. 9).

\subsection{AMMONITE AND NAUTILOID FAUNAL SPECTRUM}

The faunal spectrum study of the ectocochleate cephalopods of the LFAB is based on 1,262 ammonites and 58 nautiloids collected or studied in situ, and by 29 ammonites and 1 nautiloid published in DeLANOY et al. (2018).

The most represented ammonites families in the lower Aptian of the LFAB are Ancyloceratidae, Deshayesitidae, Douvilleiceratidae, and Desmoceratidae (Fig. 18). This faunal spectrum is consistent with the palaeogeography of the LFAB during the early Aptian times, located in the outer neritic domain. Ancyloceratidae and Nautiloidea (WARD, 1987; HEWITT, 1989; WESTERMANN, 1990, 1996) have a preferential tro- pism for the neritic domain, Deshayesitidae are open oceanic surface organisms, Douvilleiceratidae are opportunistic (BULOT et al., 2005; DUTOUR, 2005) and Desmoceratidae, Phylloceratidae and Lytoceratidae are deeper water environmental representatives (WESTERMANN, 1990, 1996; BuLOt et al., 2005).

The most spectacular character of the lower Aptian ammonite fauna of the LFAB is the abundance of the heteromorphic genus Ammonitoceras in the $D$. deshayesi and $D$. furcata Zones, with $80.2 \%$ of the Ancyloceratidae of the $D$. deshayesi Zone and $91.9 \%$ for the $D$. furcata Zone respectively. Such an abundance has never been reported previously in the literature (KAKABADZE, 1981; KAKABADZE \& HOEDEMAEKER, 2004). It may be related to particularly favourable environmental conditions in the LFAB.

The scarcity of representatives of the genus Tropaeum in the LFAB may be related to the fact that this is a boreal taxon (CASEY, 1960; AgUIRRE-URRETA, 1985). Nautiloidea never represent more than $13.5 \%$ of the ectocochleate cephalopod fauna (Fig. 18).

The proportion of each group of ectocochleate cephalopods varies over the stratigraphic interval considered: excluding data from the Combe de Joinet Member and the Pont de la Cerise Member below the Ammonitoceras Level due to the small amount of material collected (respectively 10 and 15 specimens; Fig. 18), there is a decrease in the proportion of Nautiloidea and Ancyloceratidae over time and an increase of Deshayesidae and Desmoceratidae (the latter being related to the "bloom" of the genus Aconeceras HYATT, 1903, in the D. furcata Zone). This is strongly consistent with the transgressive trend of the studied series (see Chapter 2), where open marine environment taxa become progressively more prevalent. At the top of the studied series, in the $D$. dufrenoyi Subzone, this phenomenon leads to a faunal spectrum similar to that observed in hemipelagic environments, where the ammonite populations are mainly composed of Deshayesitidae and Desmoceratidae (DuTOUR, 2005, Fig. 22). The proportion of Helicancylidae is higher when Ancyloceratidae decrease, as a result of ecologi-cal interactions between these two families.

\section{Conclusion}

The marly deposits of the Les Ferres Aptian Basin (LFAB) are located in one of the few areas of the southern margin of the Vocontian Basin where ammonites from the $D$. deshayesi - $D$ furcata Zones can be studied under favourable conditions. An abundant bed-by-bed collection of ammonites, constrained at the subzone level and represented by a significant proportion of adult or subadult specimens was collected. The lithostratigraphy and biostratigraphy of the marly Aptian of Les Ferres presented in the present article aims to serve as a 
basis for our future palaeontological work in this area. The whole marly Aptian of the LFAB is represented by a newly described lithological unit: the Les Graous Formation. This unit is divided into 3 members (from bottom to top): 1 ) the Combe de Joinet, 2) the Pont de la Cerise and 3) the Les Graous Members. Most of the collected ammonites come from a precise level at the top of the Pont de la Cerise Member, the Ammonitoceras Level (upper D. multicostatus Subzone, $D$. deshayesi Zone), and from the lower part of the Les Graous Member ( $D$. grandis and $D$. furcata Subzones). One of the most remarkable features of this fauna is the abundance of the heteromorphic ammonite genus Ammonitoceras (Ancyloceratidae). The abundant collected material allows us to formulate hypotheses on the intraspecific variability and the evolutionary modalities of several taxons of the families Ancyloceratidae, Douvilleiceratidae, Deshayesitidae, Parahoplitidae, and Desmoceratidae, which will be the topic of forthcoming contributions.

\section{Acknowledgements}

We warmly thank Pierre Ropolo for providing data about the lower Aptian Ancyloceras of the Cassis-La Bédoule area. The constructive comments of the Editor-in-chief and reviewers Ottilia SzIVEs (Budapest, Hungary) and Yves DUTOUR (Aix-en-Provence, France) are highly appreciated and greatly improved the manuscript. We are grateful to Simon MITCHELL for the improvement of the English manuscript.

\section{Bibliographic references}

AguirRe-URretA M.B. (1985).- Ancyloceratidos (Ammonoidea) Aptianos de la Cordillera Patagonica Austral, Provincia de Santa Cruz, Argentina.- Boletin de la Academia Nacional de Ciencias, Cordoba, vol. 56, no. 3-4, p. 135-257.

Baraboshikin E.J. \& Mikhailova I.A. (2002).- New stratigraphic scheme of the lower Aptian in the Volga River middle courses.- Stratigraphy and Geological Correlation, Moscow, vol. 10 , no. 6, p. 603-626 (English translation).

BERSAC S. \& BERT D. (2012).- Ontogenesis, variability and evolution of the Lower Greensand Deshayesitidae (Ammonoidea, Lower Cretaceous, Southern England): reinter-pretation of literature data; taxonomic and biostratigraphic implications.- Annales du $\mathrm{Mu}$ séum d'Histoire Naturelle de Nice, vol. XXVII, p. 197-270.

BERSAC S. \& BERT D. (2015).- Two ammonite species under the same name: revision of Deshayesites deshayesi (d'OrBIGNY, 1841) based on topotype material (Lower Aptian, Lower Cretaceous, Northeast of France).Annales de Paléontologie, Paris, vol. 101, no. 4, p. 265-294.

BERSAC S. \& BERT D. (2018).- Revision of the lower Aptian (Lower Cretaceous) ammonite species Cheloniceras cornuelianum (d'OrBIGNY, 1841).Annales de Paléontologie, Paris, vol. 104, no. 1, p. $45-70$.

Bersac S., Bert D. \& Delanoy G. (2010).- Description, biostratigraphie et interprétation des séries condensées du Crétacé inférieur de la Montagne de Ruth, à l'extrémité sud orientale de l'Arc de Castellane (Alpes-Maritimes, S-E. de la France).- Annales du Muséum d'Histoire Naturelle de Nice, vol. XXV, p. 1-17.

Bersac S., Bert D. \& Matrion B. (2012).- Revision of the index-species Deshayesites deshayesi (Ammonoidea, Lower Aptian, Lower Cretaceous): Taxonomic and biostratigraphic consequences. In: BERT D. \& BERSAC S. (eds.), First meeting of the Research Group for Paleobiology and Biostratigraphy of the Ammonites.- Boletin del Instituto de Fisiografia y Geologia, Rosario, vol. 82, p. 31-33.

BERT D. (2014, unpublished).- L'influence de la variabilité intraspécifique sur la taxinomie, la biostratigraphie et l'évolution des ammonites: une approche paléobiologique. Exemples pris dans le Jurassique supérieur et le Crétacé inférieur.PhD thesis, Université de Rennes 1, $523 \mathrm{p}$.

BERT D. \& BERSAC S. (2011).- Buts et méthodes du "levé de coupe".- Fossiles, Saint-Julien-du-Pinet, no. 6, p. 49-61.

Bert D., Bersac S., Delanoy G. \& Canut L. (2013).Palaeontology, taxonomic revision and variability of some species of the genus Gassendiceras BERT et al., 2006 (Ammonitina, Upper Barremian) from southeastern France.- Acta Geologica Polonica, Warsaw, vol. 63, no. 3, p. 355397.

BRÉHERET J.-G. (1997).- L'Aptien et l'Albien de la Fosse vocontienne (des bordures au bassin): Évolution de la sédimentation et enseignement sur les évènements anoxiques.- Bulletin de la Société géologique du Nord, Lille, vol. 25, 614 p.

BuLOT L.G. (2010).- Appendix: Systematic paleontology of Aptian and Albian ammonites from southwest Iran. In: VINCENT B., VAN BUCHEM F.S.P., Bulot L.G., ImMEnhauser A., CARON M., BAGHBANi D. \& HuC A.Y. (eds.), Carbon-isotope stratigraphy, biostratigraphy and organic matter distribution in the Aptian-Lower Albian successions of southwest Iran (Dariyan and Kazhdumi formations).- GeoArabia Special Publication, Bahrain, vol. 4, no. 1, p. 139-197.

Bulot L.G., BEAUdoin B. \& DAuphin L. (2005).- Modification de la structure des populations d'ammonites dans l'Aptien inférieur sommital et l'Aptien supérieur du domaine vocontien (SE France). In: GRoshenY D. (ed.), Impact environnemental sur la dynamique des populations au Crétacé. Volume des Résumés.- Réunions thématiques du Groupe Français du Crétacé, Paris, p. 15-17. 
Bulot L.G., FRAU C. \& PicteT A. (2017).Revision of Toxoceratoides royeri (d'ORBIGNY, 1842 ) and its bearing on the systematics of the Aptian Acrioceratidae VermeULen, 2004 (Ammonoidea, Ancyloceratina, Ancyloceratoidea).- Cretaceous Research, vol. 88, p. 187-196.

CASEY R. (1960).- A monograph of the Ammonoidea of the Lower Greensand, part 1.- Palaeontographical Society, London (1959), ixxxxvi + p. 1-44.

CASEY R., BAYLISS H.M. \& Simpson M.I. (1998).Observations on the lithostratigraphy and ammonite succession of the Aptian (Lower Cretaceous) Lower Greensand of Chale Bay, Isle of Wight, UK.- Cretaceous Research, vol. 19 , p. 511-535.

CONTE G. (1999).- Éléments de la faune de l'Aptien inferieur (Bédoulien) de Serviers-laBaume (Gard).- Bulletin de la Société d'Étude des Sciences Naturelles de Nîmes et du Gard, no. 62, p. 11-15.

Cotillon P. (1971).- Le Crétacé inférieur de l'arc subalpin de Castellane entre l'Asse et le Var; stratigraphie et sédimentologie.- Mémoires du B.R.G.M., Orléans, no. 68, 313 p.

Cotillon P. (2010).- Sea bottom current activity recorded on the southern margin of the Vocontian basin (southeastern France) during the lower Aptian. Evidence for a climatic signal.- Bulletin de la Société géologique de France, Paris, t. 181 , no. 1 , p. 3-18.

DARDEAU G. (1987).- Inversion du style tectonique et permanence des unités structurales dans l'histoire mésozoïque et alpine du basin des Alpes-Maritimes, partie de l'ancienne marge passive de la Téthys.- Comptes Rendus de l'Académie des Sciences (Série II), Paris, t. 305, p. 483-486.

DARDEAU G. \& GRACIANSKY P.-C. de (1987).- Indices d'une tectonique synsédimentaire distensive d'âge crétacé inférieur dans la basse vallée de l'Estéron (Alpes-Maritimes) et conséquences géodynamiques.- Bulletin de la Société géologique de France (8e Série), Paris, t. III, no. 6, p. 1207-1210.

DAUPHIN L. (2002, unpublished).- Litho-, bio- et chronostratigraphie comparées dans le bassin vocontien à l'Aptien.- PhD thesis, Université de Lille 1, Villeneuve-d'Ascq, 452 p.

DelanOY G. (1998).- Biostratigraphie des faunes d'Ammonites à la limite Barrémien-Aptien dans la région d'Angles-Barrême-Castellane. Étude particulière de la famille des Heteroceratina SPATH, 1922 (Ancyloceratina, Ammonoidea).- Annales du Muséum d'Histoire Naturelle de Nice, Nice, vol. XII, 270 p.

Delanoy G., Baudouin C., Gonnet R. \& Bert D. (2008).- Sur les faunes d'ammonites (Crétacé inférieur) du niveau glauconieux de la carrière des Trois-Vernes, près de Crest
(Drôme, Sud-Est de la France).- Annales du Muséum d'Histoire Naturelle de Nice, Nice, vol. XXIII, p. 11-65.

Delanoy G., Baudouin C., Pictet A., Delattre P. \& PÉNAGÉ E. (2018).- Ancyloceratidae (Ammonoidea, Ancyloceratoidea) nouveaux ou peu connus de I'Aptien inférieur des Alpes-Maritimes (SudEst de la France).- Annales du Muséum d'Histoire Naturelle de Nice, Nice, vol. XXXII, p. 35-90.

DUMAS E. (1876).- Statistique géologique, minéralogique, métallurgique et paléontologique du Département du Gard. Deuxième partie, consti-tution géologique.- Imprimerie Bertrand, Paris, $695 \mathrm{p}$.

DUTOUR Y. (2005, unpublished).- Biostratigraphie, évolution et renouvellements des ammonites de l'Aptien supérieur (Gargasien) du bassin vocontien (Sud-Est de la France).- PhD thesis, Université Claude-Bernard - Lyon 1, 302 p.

FALLOT J.E. (1885).- Étude géologique sur les étages moyens et supérieurs du terrain crétacé dans le Sud-Est de la France.- Masson Éd., Paris, $268 \mathrm{p}$.

frau C., Bulot L.G. \& Delanoy G. (2017).- New and poorly known Aptian Acrioceratidae (Acrioceratidae, Ammonoidea) from Cassis-Roquefort-laBédoule (Bouches-du-Rhône, France).- Neues Jahrbuch für Geologie und Paläontologie Abhandlungen, Stuttgart, vol. 283, no. 3, p. 335-346.

Gauthier H., Busnardo R., Combemorel R., Delanoy G., Fischer J.-C., Guerin-Franiatte F., Joly B., KenNedY W.J., SORNAY J. \& TINTANT H. (2006).Céphalopodes Crétacés, Volume IV. In: FISCHER J.C. (ed.), Révision critique de la Paléontologie Française d'Alcide d'OrBigny.- Backhuys Publisher, Kerkwerve, 292 p.

Goguel J. (1944).- Contribution à l'étude paléogéographique du Crétacé inférieur dans le Sud-Est de la France.- Bulletin du Service de la Carte géologique de France, Paris, vol. 215, p. 1-62.

Ginsburg L., Montenat C., Baudron J.-C. \& Alziar G. (1980).- Carte géologique de la France à $1 / 50$ 000. Feuille de Roquestéron.- Bureau des Recherches Géologiques et Minières, Orléans, p. XXXVI-42.

HEWITT R.A. (1989).- Outline of research on the ecology and evolution of the Eocene nautilid cephalopods from the London Clay, England.Tertiary Research, London, vol. 10, p. 65-81.

JАCOB C. (1907).- Études paléontologiques et stratigraphiques sur la partie moyenne des terrains crétacés dans les Alpes françaises et les régions voisines.- Travaux du laboratoire de géologie de la Faculté des Sciences de Grenoble, vol. VIII, p. 280-590.

Joly B. \& Delamette M. (2008).- Les Phylloceratoidea (Ammonoidea) aptiens et albiens du bassin vocontien (Sud-Est de la France).- Carnets Geol., Madrid, vol. 8, no. M04 (CG2008_M04), $60 \mathrm{p}$. 
KAKABADZE M.V. (1981).- Ancyloceratids of the south of the USSR and their stratigraphic significance.- Trudy geologicheskogo Instituta Akademii Nauk GSSR (new series), vol. 71, 195 p. (in Russian).

Kakabadze M.V. \& Hoedemaeker P.J. (2004).- Heteromorphic ammonites from the Barremian and Aptian strata of Colombia.- Scripta Geologica, vol. 128, p. 39-182.

Klein J., Busnardo R., Company M., Delanoy G., KaKabadze M., Reboulet S., Ropolo P., VAŠíčEK Z. \& VeRMEULEN J. (2007).- Lower Cretaceous Ammonites III. Bochianitoidea, Protancyloceratoidea, Ancyloceratoidea, Ptychoceratoidea. In: Riegraf W. (ed.), Fossilium Catalogus I: Animalia.- Backhuys Publishers, Kerkwerve, $381 \mathrm{p}$

LUKENEDER A. (2015).- Ammonoid Habitats and Life History. In: KLUG C., KORN D., DE BAETS K., KRUTA I. \& MAPES R.H. (eds.), Ammonoid paleobiology: from anatomy to ecology.Topics in Geobiology, New York, vol. 43, p. 689-791.

MASSE J.P. \& Fenerci-Masse M. (2011).- Drowning discontinuities and stratigraphic correlation in plateform carbonates. The late Barremian early Aptian record of southeast France.- Cretaceous Research, vol. 32, no. 6, p. 659-684.

Mikhailova I.A. \& Baraboshkin E.Y. (2001).- First Finds of Lithancylus CASEY, 1960 (Ammonoidea, Ancyloceratidae) in the Lower Aptian of Ul'yanovsk Povolzhie (Volga Region).- Paleontological Journal, Moscow, vol. 35, no. 4 , p. 367-378.

Pictet A., Delanoy G., Baudouin C. \& Boselli P. (2009).- Le genre Lithancylus CASEY, 1960 (Ammonoidea, Ancyloceratina) dans l'Aptien inférieur du Couloir rhodanien (Drôme, SudEst de la France).- Revue de Paléobiologie, Genève, vol. 28, no. 2, p. 491-509.

Pictet A., Delanoy G., Adatte T., Spangenberg J.E., Baudouin C., Boselli P., Boselli M., KINDLER P. \& FölLMi K.B. (2015).- Three successive phases of platform demise during the early Aptian and their association with the oceanic anoxic Selli episode (Ardèche, France).- Palæogeography, Palæoclimatology, Palæoecology, vol. 418, p. 101-125.

RAGAZZI M. (1982, unpublished).- L'Aptien dans les Alpes Maritimes: stratigraphie, paléoécologie, sédimentologie.- PhD thesis, Université de Nice, $224 \mathrm{p}$.

Reboulet S, Szives O., Aguirre-Urreta B., BarragÁn R., Company M., Frau C., Kakabadze M.V., Klein J., MoReno-Bedmar J.A., LUKeneder A., Pictet A., Ploch I., Raisossadat S.N., VašíčeK Z., Baraboshkin E.J. \& Mitta V.V. (2018).Report on the 6th International Meeting of the IUGS Lower Cretaceous Ammonite Working Group, the Kilian Group (Vienna, Austria, 20th August 2017).- Cretaceous Re- search, vol. 91, p. 100-110.

Roch É. (1927).- Étude stratigraphique et paléontologique de l'Aptien inférieur de la Bédoule (près Cassis) (Bouches-du-Rhône).- Mémoires de la Société géologique de France (Nouvelle Série), Paris t. IV, no. 8, p. 5-37.

Ropolo P., Conte G., Gonnet R., Masse J.-P. \& MoulLADE M. (1998).- Les faunes d'Ammonites du Barrémien supérieur/Aptien inférieur (Bédoulien) dans la région stratotypique de Cassis-La Bédoule (SE France): état des connaissances et propositions pour une zonation par Ammonites du Bédoulien-type.- Géologie Méditerranéenne, Marseille, vol. 25, no. 3-4, p. 167-175.

SARKAR S.S. (1955).- Révision des ammonites déroulées du Crétacé inferieur du Sud-Est de la France.- Mémoires de la Société géologique de France (Nouvelle Série), Paris, vol. 72, 176 p.

SAYN G. (1920).- Les Phylloceras gargasiens du Sud-Est de la France (Espèces nouvelles ou peu connues). In: KiLIAN W. (ed.), Contributions à l'étude des Céphalopodes paléocrétacés du SudEst de la France.- Mémoires pour servir à l'explication de la carte géologique détaillée de la France, Paris, p. 191-203.

THIEULOY J.P. (1990).- Un ancyloceratide géant de l'Aptien du Gard (France). Toxoceratoides? sp. inc. "gigantomorphe godeti" nov.- Géologie Alpine, Grenoble, vol. 66, p. 101-106.

THOMEL G. (1963).- Considération sur la faune gargasienne du Sud-Est de la fosse vocontienne.Travaux du Laboratoire de Géologie de la Faculté des Sciences de Marseille, Marseille, t. 7, p. 47-58.

Thomel G. (1964).- Les zones d'Ammonites de l'Aptien des Basses-Alpes.- Comptes Rendus de I'Académie des Sciences, Paris, groupe 9, t. 258 , p. $4308-4310$.

Thomel G. (1968).- À propos de l'Ammonoceratites (Argonauticeras) depereti (KILIAN) du Gargasien des Basses-Alpes orientales.- Bulletin de la Société géologique de France (7e Série), Paris, t. $X$, p. 684-687.

VAŠíčEK Z., RABRENOVIĆ D., SKUPIEN P., RADULOVIĆ V. J., RADULOVIĆ B. V. \& Mojsić I. (2014).- Am-monites (Phylloceratina, Lytoceratina and Ancyloceratina) and organic-walled dinoflagellate cysts from the Late Barremian in Boljetin, eastern Serbia.- Cretaceous Research, vol. 47, p. 140159

Vermeulen J., Lazarin P., Lepinay P., Leroy L., MascaRELLI E. \& PACAUD J.-M. (2015).- Nouvelles données sur le genre Ptychoceras OrBIGNY, 1842 et sur son espèce-type (Mollusca, Cephalopoda, Ammonoidea).- Annales du Muséum d'Histoire Naturelle de Nice, vol. XXX, p. 1-12.

WARD P.D. (1987).- The natural history of Nautilus.- Allen \& Unwin eds., Boston, 267 p.

WestermanN G.E.G. (1990).- New developments in ecology of Jurassic-Cretaceous ammonoids. In: Pallini G., Cecca F., Cresta S. \& Santantonio M. (eds.), Fossili, evoluzione, ambiente.- Atti II 
Conventione Internationale Pergola, 1987, Tecnostampa, Ostra Vetere, p. 459-478.

Westermann G.E.G. (1996).- Ammonoid life and habitat. In: LANDMAN N.H., TANABE K. \& DAVIS R.A. (eds.), Ammonoid Paleobiology.- Topics in Geobiology, New York, vol. 13, p. 607707.
Wright C.W., CALLOMON J.H. \& HOWARTH M.K. (1996).- Treatise on Invertebrate Paleontology. Part L, Mollusca 4 (revised), Volume 4: Cretaceous Ammonoidea.- The Geological Society of America, Boulder; the University of Kansas, Lawrence, $362 \mathrm{p}$. 


\section{Plates}

Plate 1: Cephalopods of the last bed of the Hauterivian-Aptian limestones (Deshayesites forbesi Zone). All specimens: BERSAC's collection.

Fig. 1: Ancyloceras sp., SBC.06061-00007/CLE037, CLE section, Bed 400.

Fig. 2: Ancyloceras rochi SARKAR, 1955, SBC.06061-00007/CLE032, CLE section, Bed 400.

Fig. 3: Ancyloceras sp., SBC.06061-00008/CRS022, CRS section, Bed 400.

Figs. 4-5: Deshayesites sp., SBC.06061-00007/CLE030, CLE section, Bed 400.

Fig. 6-7: Procheloniceras sp., SBC.06061-00007/CLE039, CLE section, Bed 400.

Fig. 8: Pseudohaploceras sp., SBC.06061-00008/CRS023, CRS section, Bed 400.

Fig. 9: Cymatoceras neckerianus (PICTET, 1847), SBC.06061-00008/CRS014, CRS section, Bed 400. 


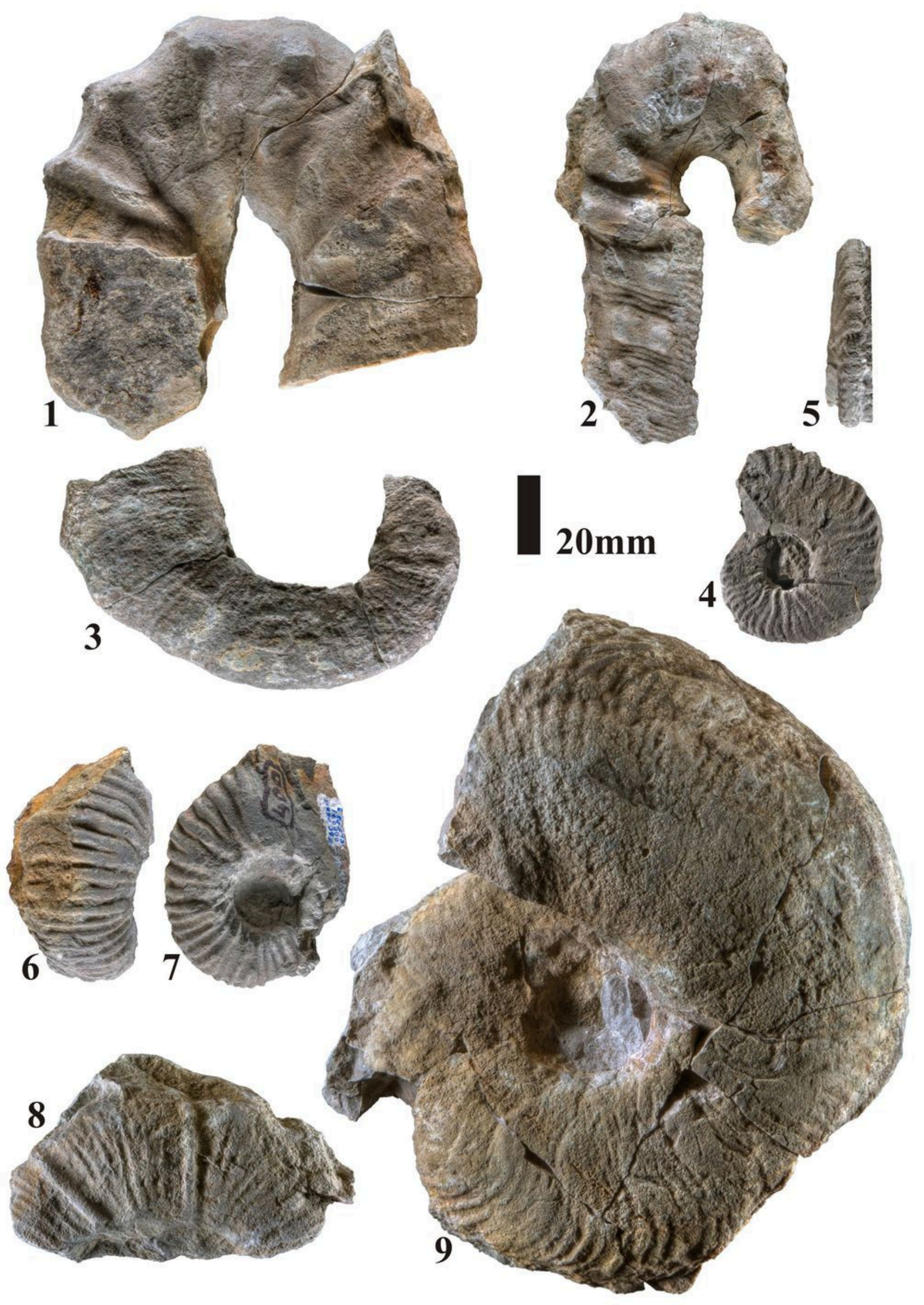


Plate 2: Fossils of the Ammonitoceras Level (top of the Pont de la Cerise Member, Dehayesites deshayesi Zone, Deshayesites multicostatus Subzone). Scale bar $50 \mathrm{~mm}$ for figures 1 to 17 . Scale bar $10 \mathrm{~mm}$ for figures 18 to 20 . All specimens: BERSAC's collection.

Figs. 1-2: Ammonitoceras ucetiae DUMAS, 1876, macroconch, SBC.06061-00006/CHP249, CHP section, Bed 415.

Figs. 3-5: Ammonitoceras ucetiae DuMAS, 1876, microconch, SBC.06061-00006/CHP276, CHP section, Bed 415.

Figs. 6-8: Deshayesites multicostatus SWINNERTON, 1935, SBC.06061-00006/CHP168, CHP section, Bed 415.

Figs. 9-10: Pseudohaploceras liptoviensis (ZEUSCHNER, 1856), SBC.06061-00006/CHP274, CHP section, Bed 415.

Figs. 11-12: Lithancylus grandis (J. de C. SOWERBY, 1828), SBC.06061-00006/CHP275, CHP section, Bed 415.

Figs. 13-15: Deshayesites multicostatus SWINNERTON, 1935, SBC.06061-00006/CHP241, CHP section, Bed 415.

Figs. 16-17: Cheloniceras crassum SPATH, 1930, SBC.06061-00006/CHP171, CHP section, Bed 415.

Fig. 18: Unidentified ahermatypic coral. SBC.06061-00006/CHP455, CHP section, Bed 415.

Fig. 19: Deshayesites multicostatus SWINNERTON, 1935, SBC.06061-00006/CHP072, CHP section, Bed 415.

Fig. 20: Macroscaphites striatisulcatus (ORBIGNY, 1841), microconch, SBC.06061-00007/CLE015, CLE section, Bed 415. 


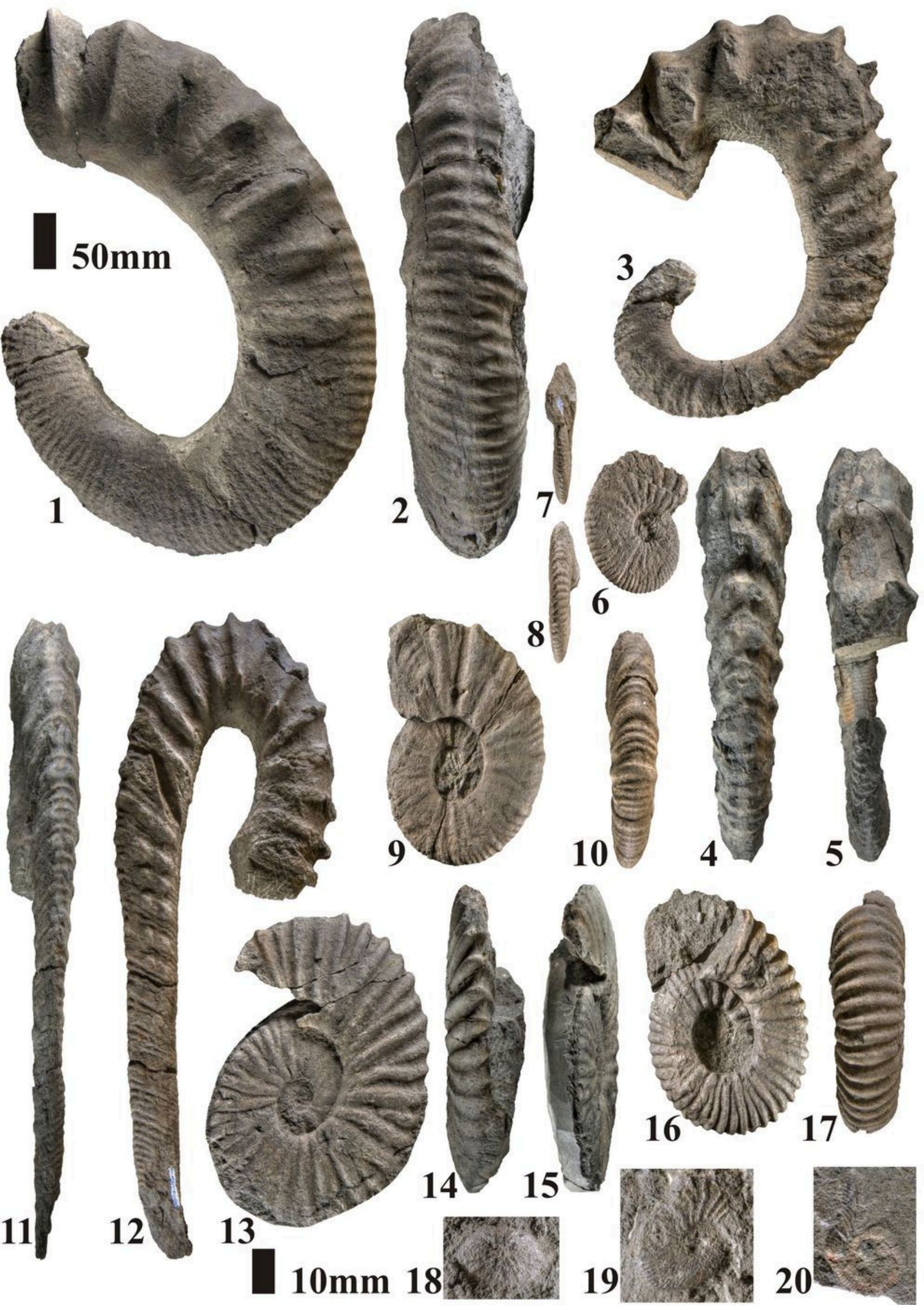


Plate 3: Cephalopods of the Toxoceratoides Bed (base of the Les Graous Member, Dehayesites deshayesi Zone, Deshayesites grandis Subzone). All specimens: BERSAC's collection.

Figs. 1-2: Pylloceras (Hypophylloceras) sp., SBC.06061-00007/CLE005, CLE section, Bed 416.

Figs. 3-4: Macroscaphites striatisulcatus (ORBIGNY, 1841), macroconch, SBC.06061-00006/CHP279, CHP section, Bed 416.

Figs. 5-6: Cheloniceras crassum SPATH, 1930, SBC.06061-00006/CHP055, CHP section, Bed 416.

Figs. 7-8: Anglonautilus sp., SBC.06061-00006/CHP278, CHP section, Bed 416.

Figs. 9-10: Deshayesites grandis SPATH, 1930, SBC.06061-00001/GRS350, GRS section, Bed 97.

Figs. 11-12: Deshayesites grandis SPATH, 1930, SBC.06061-00006/CHP124, CHP section, Bed 416.

Figs. 13-14: Toxoceratoides aff. royerianus (ORBIGNY, 1842), SBC.06061-00006/CHP128, CHP section, Bed 416.

Figs. 15-16: Toxoceratoides aff. royerianus (ORBIGNY, 1842), SBC.06061-00006/CHP100, CHP section, Bed 416. 


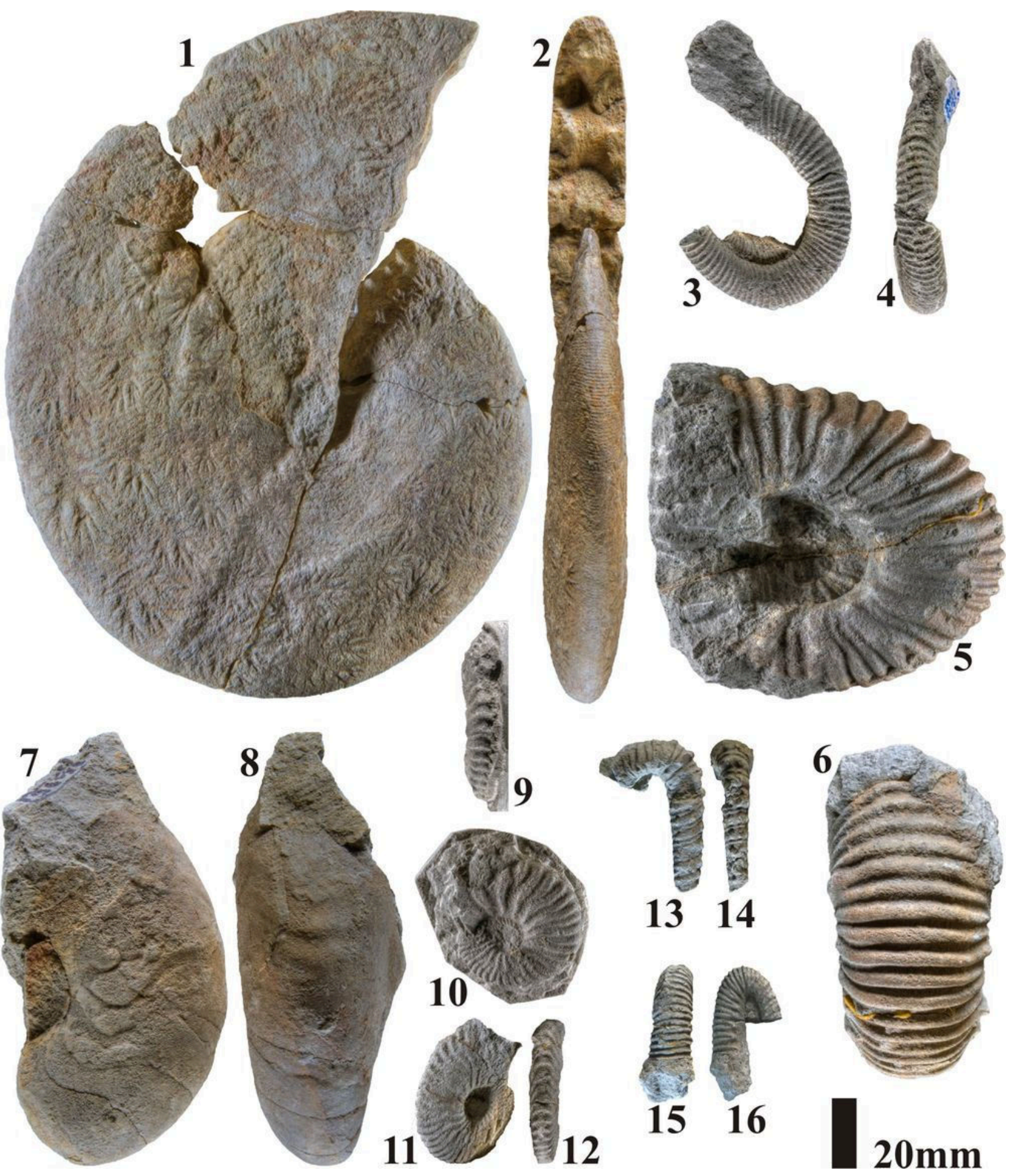


Plate 4: Cephalopods of the Les Graous Member (Dufrenoyia furcata Zone, Dufrenoyia furcata Subzone). All specimens: BERSAC's collection.

Figs. 1-3: Ammonitoceras lahuseni (Sinzow, 1906), macroconch, SBC.06061-00006/CHP277, CHP section, Bed 419.

Figs. 4-5: Acantholytoceras sp., SBC.06061-00006/CHP273, CHP section, Bed 417.

Figs. 6-7: Pseudohaploceras liptoviensis (ZEUSCHNER, 1856), SBC.06061-00006/CHP074, CHP section, Bed 419.

Figs. 8-9: Cheloniceras crassum SPATH, 1930, SBC.06061-00001/GRS341, GRS 1 section, Bed 100.

Figs. 10-11: Lytoceras sp., SBC.06061-00001/GRS210, GRS 1 section, Bed 102.

Fig. 12: Pylloceras (Hypophylloceras) sp., SBC.06061-00001/GRS146, GRS 1 section, Bed 100.

Figs. 13-14: Cymatoceras neckerianus (PICTET, 1847), SBC.06061-00001/GRS211, GRS 1 section, Bed 102. 

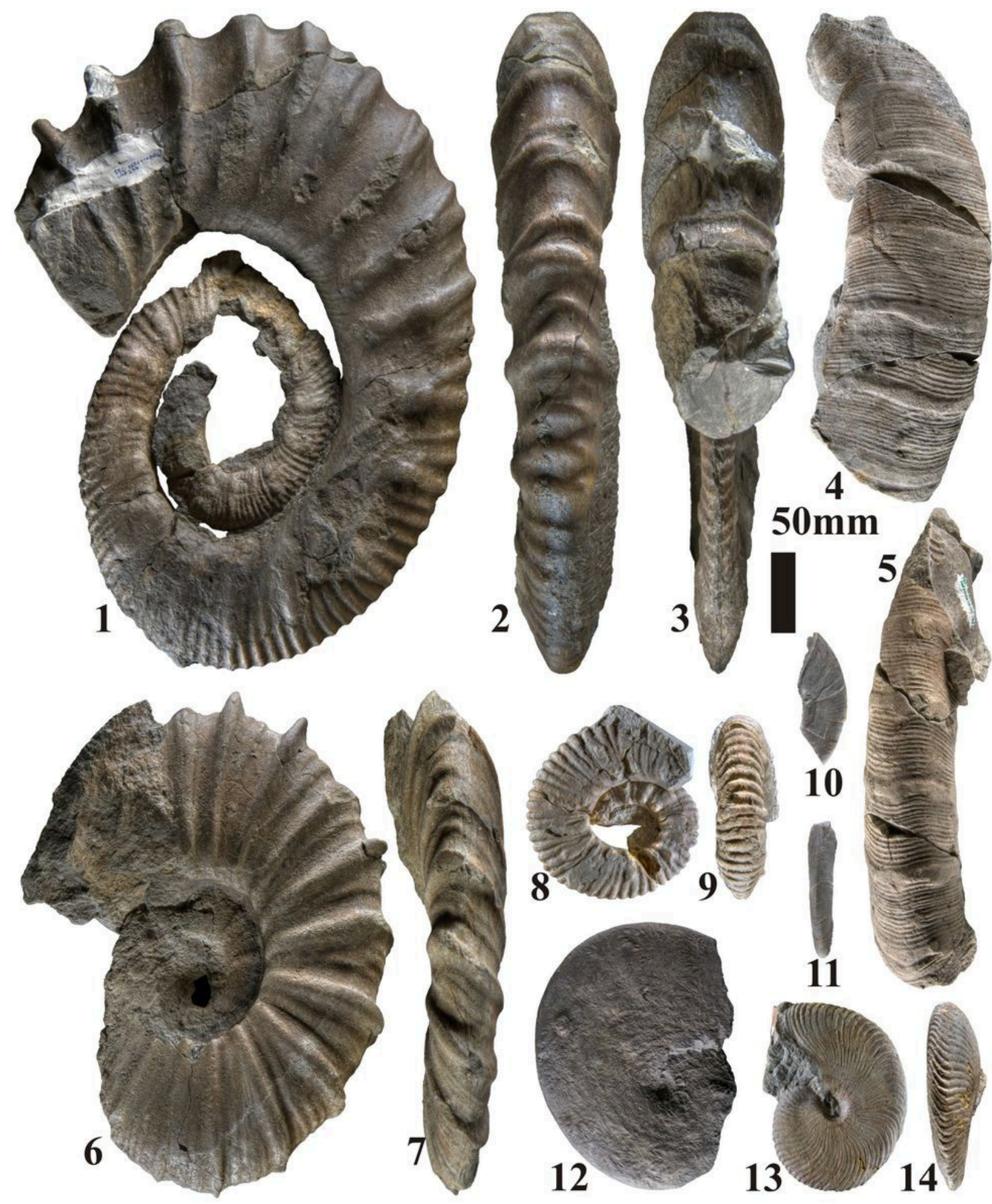
Plate 5: Fossils of the Les Graous Member. Figures 1-29: Dufrenoyia furcata Zone, Dufrenoyia furcata Subzone. Figures 30-32: Dufrenoyia furcata Zone, Dufrenoyia dufrenoyi Subzone. All specimens: BERSAC's collection. Figs. 1-2: Toxoceratoides rochi CASEY, 1961, SBC.06061-00001/GRS199, GRS 1 section, Bed 100. Figs. 3-4: Toxoceratoides rochi CASEY, 1961, SBC.06061-00001/GRS555, GRS 1 section, Bed 102. Fig. 5: Dufrenoyia furcata (J. de C. SOWERBY, 1837), SBC.06061-00001/GRS073, GRS 1 section, Bed 100. Figs. 6-7: Dufrenoyia furcata (J. de C. SowERBY, 1837), SBC.06061-00001/GRS683, GRS 1 section, Bed 102. Fig. 8: Dufrenoyia furcata (J. de C. SowERBY, 1837), SBC.06061-00001/GRS566, GRS 1 section, Bed 102. Fig. 9: Dufrenoyia furcata (J. de C. SowERBY, 1837), SBC.06061-00001/GRS597, GRS 1 section, Bed 105. Fig. 10: Colombiceras crassicostatum (ORBIGNY, 1841), SBC.06061-00001/GRS282, GRS 1 section, Bed 102. Figs. 11-12: Colombiceras crassicostatum (ORBIGNY, 1841), SBC.06061-00001/GRS394, GRS 1 section, Bed 99. Fig. 13: Aconeceras nisum (ORBIGNY, 1841), SBC.06061-00001/GRS175, GRS 1 section, Bed 100.

Fig. 14: Aconeceras nisum (ORBIGNY, 1841), SBC.06061-00001/GRS685, GRS 1 section, Bed 102.

Fig. 15. Ptychoceras emericianum ORBIGNY, 1842, SBC.06061-00001/GRS518, GRS 1 section, Bed 102.

Fig. 16: Macroscaphites striatisulcatus (ORBIGNY, 1841), microconch, SBC.06061-00001/GRS482, GRS 1 section, Bed 104.

Fig. 17: Neohibolites aptiensis (STOLLEY, 1913), SBC.06061-00001/GRS677, GRS 1 section, Bed 101. Fig. 18: Neohibolites aptiensis (STOLLEY, 1913), SBC.06061-00001/GRS682, GRS 1 section, Bed 102. Fig. 19: Duvalia grasi (Duval-Jouve, 1841), SBC.06061-00001/GRS468, GRS 1 section, Bed 104. Fig. 20: Duvalia grasi (Duval-Jouve, 1841), SBC.06061-00001/GRS674, GRS 1 section, Bed 102.

Fig. 21: Mesohibolites sp., SBC.06061-00001/GRS679, GRS 1 section, Bed 102.

Fig. 22: Semisolarium sp., SBC.06061-00001/GRS295, GRS 1 section, Bed 102.

Fig. 23: Ceratosiphon sp., SBC.06061-00001/GRS673, GRS 1 section, Bed 102.

Fig. 24: Aucellina aptiensis (ORBIGNY, 1850), SBC.06061-00001/GRS491, GRS 1 section, Bed 99.

Fig. 25: Unidentified ahermatypic coral, SBC.06061-00006/CHP228, CHP section, Bed 424.

Fig. 26: Cycloid fish scale, SBC.06061-00001/GRS369, GRS 1 section, Bed 99.

Fig. 27: Toxaster collegnoi SISMONDA, 1843, SBC.06061-00001/GRS675, GRS 1 section, Bed 106.

Fig. 28: Toxaster collegnoi SISMONDA, 1843, SBC.06061-00001/GRS676, GRS 1 section, Bed 99.

Fig. 29: ?Cyrtothyris sp., SBC.06061-00001/GRS670, GRS 1 section, Bed 102.

Figs. 30-31: Dufrenoyia dufrenoyi (ORBIGNY, 1841), SBC.06061-00001/GRS685, GRS 1 section, Bed 110.

Fig. 32: Dufrenoyia dufrenoyi (ORBIGNY, 1841), SBC.06061-00001/GRS592, GRS 1 section, Bed 113. 


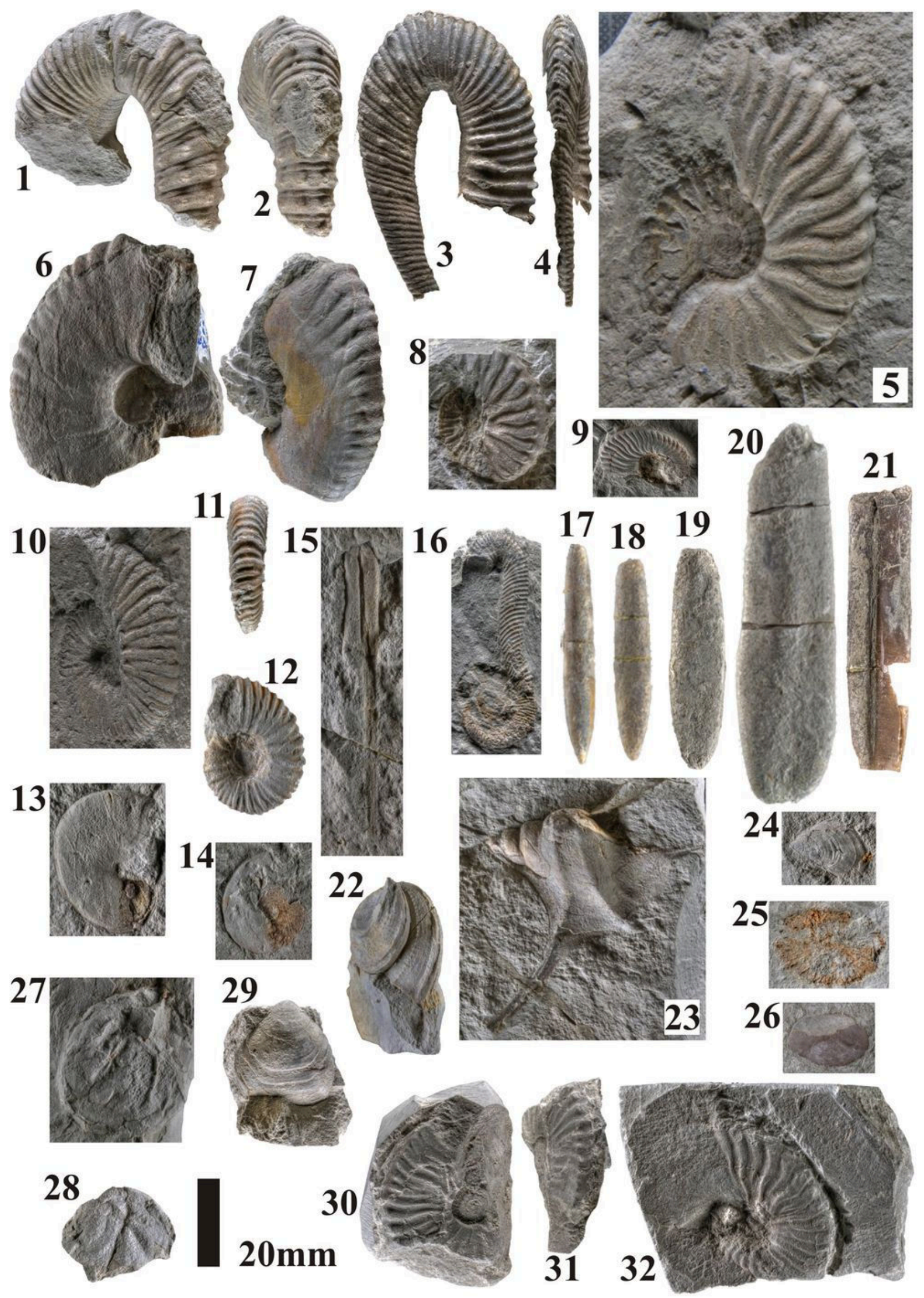

